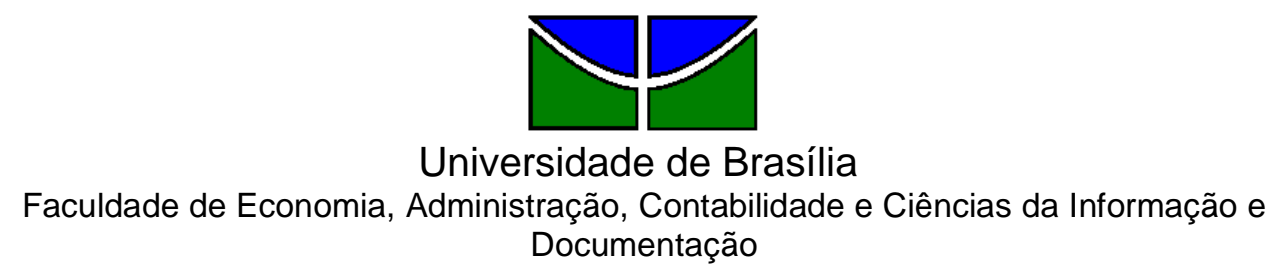

DEPARTAMENTO DE ADMINISTRAÇÃO

TRABALHO DE CONCLUSÃO DE CURSO

\title{
RISCOS DE CRÉDITO E GARANTIAS NO SETOR DE MICROFINANÇAS
}

Koné Aida Mariam

Brasília - DF

Julho / 2009 
Universidade de Brasília

Faculdade de Economia, Administração, Contabilidade e Ciências da Informação e Documentação

\author{
DEPARTAMENTO DE ADMINISTRAÇÃO
}

TRABALHO DE CONCLUSÃO DE CURSO

\title{
RISCOS DE CRÉDITO E GARANTIAS NO SETOR DE MICROFINANÇAS
}

Koné Aida Mariam

Professor Orientador:

\section{Mestre José Antônio Lopes Ramos}

"Trabalho apresentado em cumprimento às exigências acadêmicas parciais da disciplina Estágio Supervisionado em administração para a obtenção do grau de Administradora"

Brasília - DF

Julho / 2009 
Koné, Aida Mariam.

Riscos de crédito e garantias no setor de microfinanças / Koné Aida Mariam. - Brasília, 2009.

$x v i, 60$ f. : il.

Monografia (graduação) - Universidade de Brasília, Departamento de Administração, 2009.

Orientador: José Antônio Lopes Ramos, Mestre.

1. Micro e pequenas empresas. 2. Risco de crédito. 3. Microfinanças. I. Título. 
Universidade de Brasília

Faculdade de Economia, Administração, Contabilidade e Ciências da Informação e Documentação

\author{
DEPARTAMENTO DE ADMINISTRAÇÃO
}

\title{
RISCOS DE CRÉDITO E GARANTIAS NO SETOR DE MICROFINANÇAS
}

A Comissão Examinadora, abaixo identificada, aprova o Trabalho de Conclusão do Curso de Administração da Universidade de Brasília da aluna

\author{
Koné Aida Mariam \\ José Antônio Lopes Ramos, Mestre \\ Professor-Orientador \\ Pedro Meneses, Doutor \\ Professor-Examinador
}

Brasília, 10 de Julho de 2009 
A Deus, pela vida, amor, proteção, e privilégio do estudo. Ao meu pai, meu herói, pelo amor, confiança, dedicação e apoio constante que me ajudaram a seguir no caminho certo e a voar com minhas próprias asas. A minha família que confiou em mim ao longo desta jornada. Aos meus verdadeiros amigos e a todos que de alguma forma marcaram meus dias, e que eu não saberia dizer os nomes, sob pena de cometer injustiças, pelo amor, pelo apoio, companheirismo, e amizades que perpetuarão por toda minha vida. A Universidade de Brasília e respectivos mestres pelos conhecimentos que contribuíram para o sucesso deste trabalho e a minha formação acadêmica. A Caixa Econômica Federal pela experiência profissional e enriquecimento deste trabalho. E a Brasília pela oportunidade e lição de vida. 
"Esses projetos de microcrédito são a prova do que podemos fazer se investimos na economia e no potencial humano de todos os nossos cidadãos. Está ficando cada vez mais óbvio que a microempresa não só transforma vida, como também faz erguer comunidades e sociedades."

Hillary Rodham Clinton

"O autodesenvolvimento parece significar tanto adquirir mais capacidade quanto mais peso como pessoa. Ao focalizar a responsabilidade, as pessoas assumem uma visão maior com relação a si mesmas. Não se trata de vaidade, de orgulho, mas de respeito próprio e de autoconfiança. É algo que não se pode tirar da pessoa, uma vez adquirida. Está fora, e ao mesmo tempo dentro de mim." 


\section{SUMÁRIO}

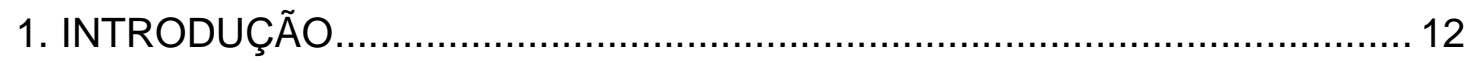

1.1. Contextualização do tema ............................................................ 13

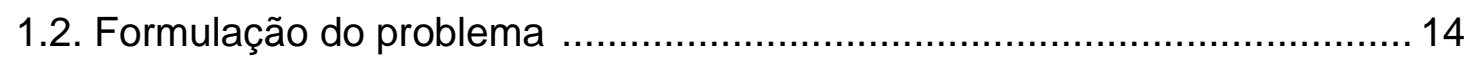

1.3. Objetivo geral................................................................................. 14

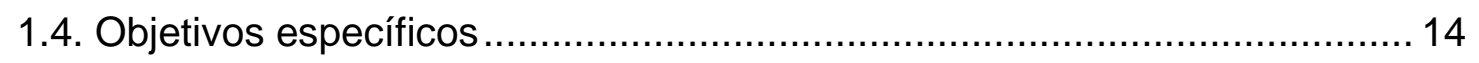

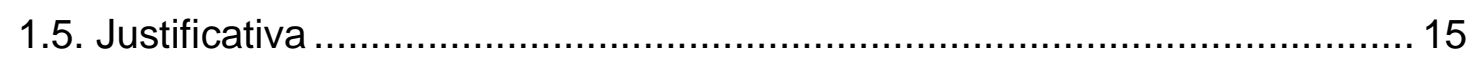

1.6. Métodos e técnicas de pesquisa......................................................... 16

1.7. Estrutura e organização do Trabalho................................................... 16

2. REFERENCIAL TEÓRICO ................................................................... 18

2.1. A importância das micro e pequenas empresas .................................... 19

2.2. Gestão bancária ......................................................................... 23

2.2.1. Mercado de crédito ................................................................... 23

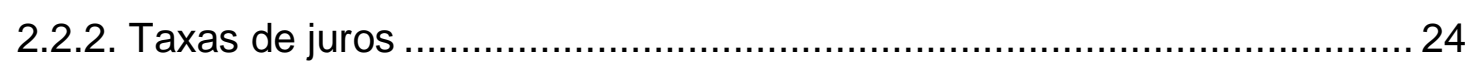

2.3. Análise de risco de crédito ............................................................ 25

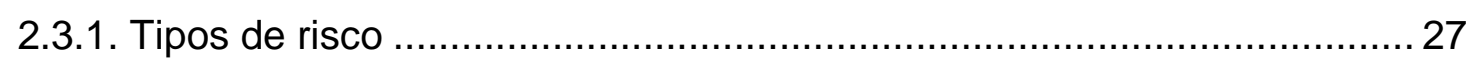

2.3.2. Processo analítico: C's do crédito.................................................... 30

2.4. Conceituação das Microfinanças .................................................... 31

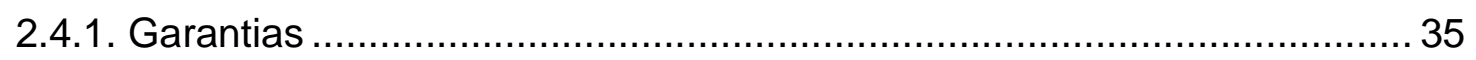

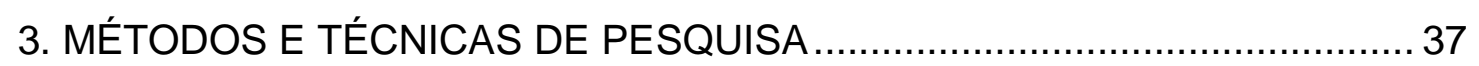

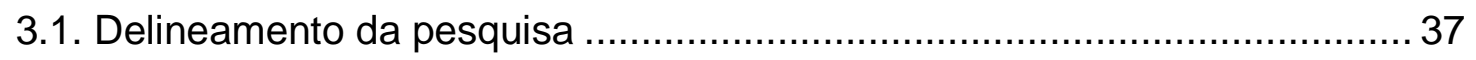

3.2. Caracterização da organização ......................................................... 39

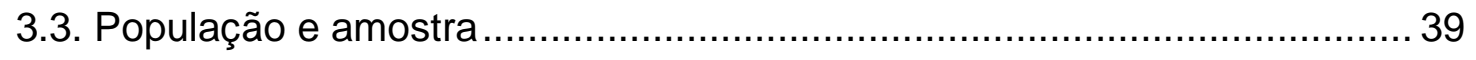

3.4. Caracterização dos instrumentos de pesquisa ....................................... 40

3.5. Procedimentos de coleta e de análise de dados................................... 40

4. APRESENTAÇÃO E ANÁLISE DOS DADOS ........................................ 41

4.1. Participantes do estudo................................................................. 41

4.1.1. Micro e pequenas empresas......................................................... 41

4.2. Linhas de crédito da Caixa Econômico Federal..................................... 44

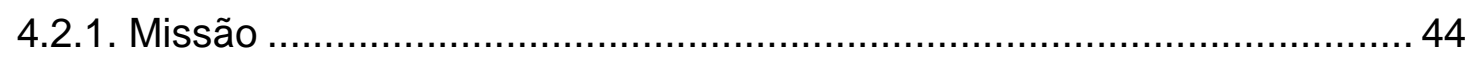

4.2.2. Análise de risco da proposta de crédito ........................................ 44 
4.2.3. Instituições de Microfinanças conveniadas.......................................... 45

4.3. Abertura de conta ......................................................................... 46

4.3.1. Características do tomador de crédito ................................................ 46

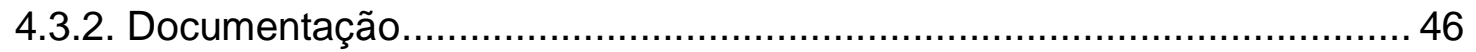

4.3.3. Parâmetros do empréstimo.................................................................. 48

4.4. Liberação e acompanhamento do empréstimo ......................................... 49

5. CONSIDERAÇÕES FINAIS ........................................................... 51

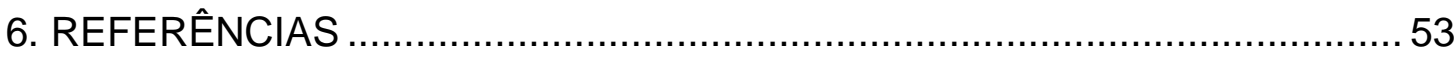

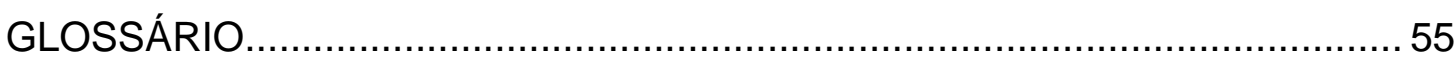

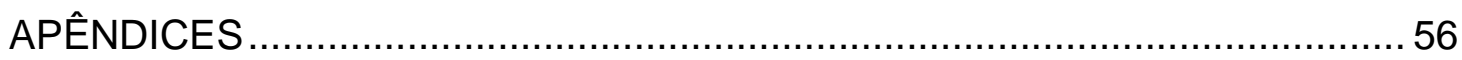

Apêndice A: Questionário às Micro e Pequenas Empresas .............................. 56

Apêndice B: Questionário à Caixa Econômica Federal .................................. 58

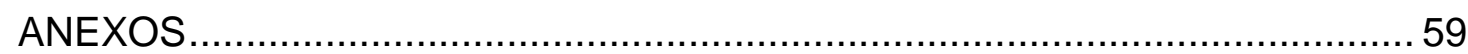

Anexo A: Fluxograma de concessão da operação Microcrédito da CEF ...........59 


\section{LISTA DE ILUSTRAÇÕES}

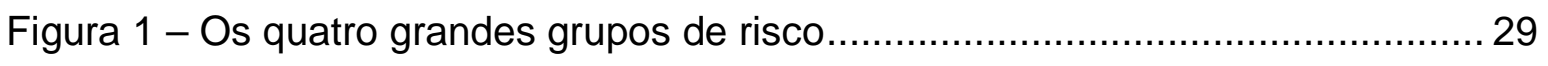

Quadro 2 - Definições de microfinanças e microcrédito ........................................ 33

Quadro 3 - Entidades especializadas em microfinanças e suas características ...... 34

Quadro 4 - Diferenças entre IFCs e IMCs ........................................................ 36

Figura 5 - Conhecimento de linhas de crédito ...................................................... 43

Figura 6 - Modelo da operação Microcrédito da CEF.......................................... 50 


\section{LISTA DE TABELAS}

Tabela 1 - Classificação das microempresas por número de empregados..............20

Tabela 2 - Motivos alegados pelas MPEs encerradas em 2006 .......................... 23

Tabela 3 - Caracterização das Empresas da Feira dos Importados e do Guará

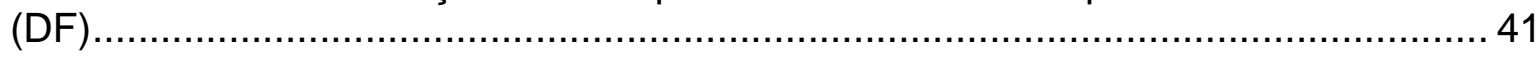

Tabela 4 - Razões e respectivos valores de empréstimos ................................. 42 


\section{RESUMO}

A circulação do fluxo monetário é indispensável para a avaliação do Produto Interno Bruto (PIB) de uma determinada economia. As empresas, independentemente do porte, são unidades produtivas que proporcionam esta circulação ao gerar emprego e renda. Quanto mais pessoas ativas, maior o alcance do desenvolvimento contínuo e sustentável. Mas um grande número de micro e pequenas empresas não se submetem ao registro formal obrigatório e dificultam a mensuração deste indicador. Elas ficam na informalidade por falta de capital para se inserir e sobreviver em um mercado instável e globalizado. $\mathrm{Na}$ busca de resolução de problemas relativos à capital de giro ou problemas deste gênero, algumas empresas optam pela sua entrada no sistema financeiro convencional. Mas elas são desiludidas ao encontrar barreiras, principalmente no segmento bancário. De um lado, a estrutura do sistema tradicional impossibilita o acesso a essas empresas por apresentarem riscos considerados altos demais. Em outros casos, quando o acesso é liberado, são cobrados juros altíssimos difícil de ser assumidos pelos empreendedores. Frente a este dilema, as microfinanças procuram atender esta parcela da população cujas necessidades não são propriamente atendidas pelas instituições tradicionais que, por sua vez, podem alcançar índices de inadimplência e riscos de crédito bastante reduzidos com uso desta ferramenta. Para tanto, este trabalho visa observar as dificuldades de ambas as partes em relação ao crédito bancário com o intuito de identificar as linhas de crédito com a metodologia microfinanceira e redutora de riscos de crédito. Para a realização deste trabalho, realizou-se um estudo exploratório com base em uma revisão bibliográfica, sobretudo de revistas e artigos sobre o assunto, além de duas pesquisas de campo junto a 80 micro e pequenas empresas em Brasília e a um analista de crédito da Caixa Econômica Federal do Brasil. Ao final da pesquisa, apesar da identificação de duas linhas de crédito alinhadas com a realidade deste segmento, foram observadas algumas falhas como a falta de divulgação dessas operações, além da necessidade de revisão dos processos e sistemas bancários para aplicação das microfinanças como meio de inserção desta parcela da população.

Palavras-chave:
1. Micro e Pequenas
2. Risco de crédito
3. Microfinanças

\section{Empresas}




\section{INTRODUÇÃO}

As experiências históricas demonstram que Keynes, um dos grandes pensadores de todos os tempos, tinha uma visão de futuro alinhada com a evolução das formas de produção e de trabalho. $O$ enfraquecimento de muitas economias leva a concordar que o desenvolvimento sustentável requer politícas fiscais e monetárias que induzam o crescimento das economias nacionais.

Existem muitas discussões acerca do conceito de desenvolvimento sustentável no contexto do crescimento ecônomico e social, entre elas a que envolve a questão do acesso ao crédito a empreendimentos e/ou pessoas menos privilegiadas. Segundo Furtado (2001) apud Haddad (2006, p.14), o verdadeiro desenvolvimento é principalmente um processo de ativação e canalização de forças sociais, de melhoria da capacidade associativa, de exercício da iniciativa e da criatividade. Ele ressalta em sua obra que uma verdadeira política de desenvolvimento terá que ser a expressão das preocupações e das aspirações dos grupos sociais que tomam consciência de seus problemas e se empenham em resolvê-las. Mas como quase tudo envolve condições financeiras, há necessidade de abertura do sistema financeiro para este público em específico, ou seja, a estratégia adequada é dar o direito a cada cidadão necessitado de manifestar seu espírito empreendedor dando-lhe as matérias-primas e fazer funcionar seu potencial de criação de riqueza por meio de formação de negócio próprio.

Estudos recentes mostram que a taxa de crescimento de um país depende do nível de desenvolvimento da intermediação e da atuação dos diferentes agentes econômicos. O sistema econômico é composto de empreendedores e poupadores, e o sistema financeiro tem como função estabelecer um equilíbrio entre as demandas por investimentos e as ofertas de recursos. Os recursos, geralmente, fluem das contas dos poupadores para o financiamento de projetos ou empreendimentos mais produtivos que, por sua vez, sempre passam por algumas análises financeiras durante a intermediação bancária. Mas a difícil mensuração do risco e retorno de investimentos tornaram 
este processo ainda mais complicado. De um lado, as instituições financeiras precisam de informações para compor seus bancos de dados e mensurar fatores cruciais como risco e retorno para sua tomada de decisão. De outro lado, as micro e pequenas empresas não possuem a estrutura, a formalização de negócio e balanços necessários para se enquadrarem nos padrões bancários. Isto resulta em assimetria de informação e impossiblidade de concessão de crédito para este segmento por ser considerada uma operação de alto risco.

\subsection{Contextualização do tema}

A desaceleração do crescimento mundial nos últimos anos não impediu o avanço da democracia participativa e da descentralização do capital no mercado de trabalho. Este fato marca mudanças nas concepções quanto à importância das micro e pequenas empresas e seu papel na luta contra a volta do desemprego em massa, uma crise que está estrangulando muitas economias, tanto desenvolvidas quanto as que estão em processo de crescimento. As micro e pequenas empresas (MPEs) respondem pela grande maioria das unidades produtivas criadas anualmente. Felizmente, a criação dessas MPEs permite a geração de novas oportunidades e o sustento de varias nações, aquecendo assim a economia global. Infelizmente, a maioria dos bancos tradicionais focaliza seus produtos e serviços nas grandes empresas e corporações, em vez de destinaram uma parte significativa de seus recursos ao investimento e promoção desses empreendimentos solidários que podem ser hoje, em uma época de crise mundial, a salvação de muitos paises.

Os bancos tradicionais não conseguem avaliar precisamente a qualidade creditícia dos clientes deste segmento e devido à falta de informações, é dificultado o acesso às fontes de capital a custos competitivos. Esses empreendimentos acabam desaparecendo e muito do potencial de crescimento de uma localidade é desperdiçado. As restrições financeiras impostas pelo mercado financeiro promovem a concentração de riqueza, do mercado e inviabilizam a competitividade $e$, conseqüentemente, 0 desenvolvimento econômico democrático e sustentável. 
O desenvolvimento das micro e pequenas empresas depende do apoio ao crédito, que é realizado principalmente através das concessões de garantias de crédito. Mas o sistema financeiro tradicional ainda não atingiu a flexibilidade exigida para permitir a inserção deste público no mercado de crédito sem necessidade de taxas de juros exorbitantes. Percebe-se que é necessário linhas de crédito ou produtos bancários deste tipo para este segmento. Esta necessidade é supprida, de uma forma, pelas microfinanças. A utilidade desta ferramenta é diferenciada porque ameniza as restrições impostas pelos bancos tradicionais e possibilita a realização de projetos viáveis reduzindo as taxas de juros. As microfinanças são de uma forma mais ampla, uma gama de serviços necessários para colocar em prática micro e pequenos projetos de geração de renda.

\subsection{Formulação do problema}

Por meio desta pesquisa, procurou-se responder a seguinte interrogação: Quais são as linhas de crédito microfinanceiro disponíveis que podem servir, de um lado, de instrumento prático e inovador na busca da inclusão dos agentes econômicos informais no sistema financeiro e, de outro, como solução para a redução de risco para as instituições financeiras que atuam neste segmento?

\subsection{Objetivo geral}

A presente pesquisa tem como objetivo geral identificar as linhas de crédito e alternativas de garantias que se enquadram no conceito das microfinanças, na busca de maior participação das micro e pequenas empresas no crescimento econômico e redução de riscos de crédito bancário para a viabilização de empréstimos de alto risco.

\subsection{Objetivos específicos}

- Identificar os entraves sofridos pelas micro e pequenas empresas no acesso ao crédito;

- Analisar os procedimentos bancários no mercado de crédito; 
- Descrever as linhas de crédito e programas que atendem aos micro e pequenos empreendimentos;

- Comparar as microfinanças com o sistema tradicional brasileiro;

\subsection{Justificativa}

Para que atores da economia informal e formal de baixa renda, excluídos do mercado convencional de crédito, consigam se deslocar de baixo para acima da linha do desemprego, esses precisam ter acesso a certos serviços financeiros que poderiam servir de suporte para a criação de potenciais empreendimentos. Os mercados de trabalho e de produção são ambientes bastante turbulentos devido à globalização e abertura de mercado. Tanto grandes quanto pequenas empresas encontram dificuldades no seu ciclo de vida, mas as pequenas são mais atingidas por não terem a estrutura e recursos necessários para se prevenir e crescer. Por este motivo, as micro e pequenas procuram alternativas de financiamento.

Os bancos tradicionais, geralmente, servem de meio para o financiamento de projetos viáveis, gerando o crescimento das forças produtivas de uma determinada localidade. Mas eles nem sempre podem efetuar operações de empréstimos se os clientes não se enquadrarem nas políticas préviamente estabelecidas pela instituição. Os projetos de negócio dos micro e pequenos empreendedores apresentam riscos altos demais, o que dificulta a liberação de empréstimos. E quando liberado, são cobrados juros exorbitantes que induzem o tomador de empréstimo a se endividar ainda mais.

As empresas de pequeno porte têm um papel crucial no desenvolvimento de uma localidade ou região. Além de ser uma fonte de geração de emprego e, consequentemente, de renda, as micro e pequenas empresas promovem a inclusão social e redução de desigualdades. Desta forma, para canalizar talentos e habilidades dentro de potenciais empreendedores de uma forma massiva e mais efetiva, deve-se buscar alternativas adequadas para esta situação. Linhas de crédito e serviços bancários direcionadas a este segmento levariam a um win-win situation, ou seja, ao oferecer este tipo de serviços, os bancos 
reduziriam seus riscos e em troca, as MPEs teriam os intrumentos que os permitissem ter uma visão mais clara do mercado financeiro, dos riscos causados pelas constantes mudanças no cenário internacional que afeta o nacional, e outros desafios como a competitividade que fazem parte do dia-dia de qualquer empreendimento.

As populações menos favorecidas, em vez de serem consideradas como um problema, devem ser vistas como uma solução vantajosa para as instituições financeiras porque estas últimas podem criar um novo segmento que permite a penetração de novos usuários no mercado. Além de expandir seus serviços, as Instituições Financeiras de Microfinanças (IFM) podem captar recursos do público, oferecer títulos de capitalização, poupança programada, atuando assim nas duas pontas do crédito: na oferta e na captação. Assim, é possível utilizar esta estratégia para estabelecer um ponto de consenso entre essa parte da população e os agentes financeiros.

\subsection{Métodos e técnicas de pesquisa}

Esta pesquisa, de natureza exploratória e descritiva, será realizada com base em uma revisão bibliográfica, sobretudo de livros, revistas e artigos sobre o assunto e de uma pesquisa de campo.

\subsection{Estrutura e organização do trabalho}

O trabalho é estruturado em cinco capítulos. O primeiro capítulo "Introdução" expõe o problema que originou a pesquisa, a justificativa, os objetivos e as técnicas de pesquisa para sua realização.

O segundo capítulo "Referencal Teórico" descreve os conceitos que foram sujeitos à análise ao longo do trabalho e que serviram de dados para solucionar o problema exposto na introdução.

O tipo de pesquisa e os instrumentos de pesquisa utilizados para se chegar ao objetivo final são abordados no terceiro capítulo "Métodos e Técnicas de Pesquisa". 
O quarto capítulo "Apresentação e Análise de Resultados da Pesquisa" apresenta a análise descritiva dos dados coletados tanto na revisão bibliográfica quanto na pesquisa de campo.

O quinto capítulo "Considerações finais" resume de uma forma clara e direta todos os pontos tratados no trabalho e faz algumas recomendações.

E por fim, são listadas as referências bibliográficas que serviram de apoio, seguido do glossário, apêndices e anexos. 


\section{REFERENCIAL TÉORICO}

As microfinanças, antigamente conhecidos simplesmente por microcrédito, representam um segmento do setor financeiro voltado para um público cujas necessidades não são propriamente atendidas pelas instituições tradicionais. Geralmente o público alvo das microfinanças faz parte da economia informal, ou seja, são agentes que não se submetem ao registro formal obrigatório, que trabalhem por conta própria, e que sobrevivem de micro e pequenos empreendimentos. Segundo pesquisa do IBGE (Instituto Brasileiro de Geografia e Estatística) em 2003, as MPE constituem uma alternativa de ocupação para uma parcela da população que tem condição de desenvolver seu próprio negócio, mas que tem pouca ou nenhuma qualificação, e que não encontra emprego nas empresas de maior porte. As microfinanças, além de ser uma modalidade de investimento de grande importância no combate à pobreza, funcionam como um mecanismo capaz de amenizar a concentração de renda e as desigualdades entre ricos e pobres.

Diferente do microcrédito, que era somente um empréstimo, as microfinanças constituem uma gama de serviços (treinamento/educação, conta poupança, seguro, moradia etc) que são considerados necessários ao(s) agente(s) requisitor (es) do crédito. As operações são normalmente menos custosas e o custo/risco operacional é reduzido nas operações. O acesso ao crédito é facilitado com esta ferramenta devido às baixas taxas de juros e o relacionamento cliente-banco (estratégia de controle) que aumenta em ambas as partes a confiança, porporcionando harmonia e democracia no sistema financeiro.

Portanto, este capítulo destina-se à exposição dos dados encontrados na revisão bibliográfica e que são pontos importantes para o desenvolvimento da pesquisa. Estas informações servem de apoio para a explicação de elementos essenciais para se chegar ao ponto decisivo da pesquisa que trata das microfinanças como uma possível solução para o problema das micro e pequenas empresas e a gestão de risco das instituições financeiras. 


\subsection{A importância das micro e pequenas empresas}

O crescimento e desenvolvimento econômico de um determinado país dependem do nível de produtividade das suas forças produtivas. De acordo com Haddad (2006), o desenvolvimento de uma localidade em longo prazo está diretamente relacionado à sua idoneidade de organização social e política para moldar o futuro da região, mas para que os agentes locais possam criar micro ou pequenos empreendimentos geradores de renda, a localidade deve dispor de diferentes formas de capitais intangíveis.

Analisando o mercado global, percebe-se que os micro e pequenos negócios servem de apoio para as economias locais, portanto nacionais, em caso de regressão econômica. Segundo Haddad (2006, p. 15), "quando as economias mais desenvolvidas ou menos desenvolvidas entram num processo de regressão econômica, a sua reação posterior dependerá das características estruturais e político-institucionais das sociedades locais".

Ou seja, se uma economia forte tiver uma regressão devido a eventos externos e a economia assumir os indicadores de renda per capita, de comércio e de produtividade, isto pode gerar efeitos contrários (Haddad, 2006). Um exemplo disso é o caso dos países envolvidos na Segunda Guerra Mundial ou, mais recentemente, a crise imobiliária vivenciada pelos Estados Unidos. Entretanto, a economia poderá se manter parcialmente estável se forem considerados os rendimentos das pequenas e médias empresas que não têm seu setor afetado pela crise, ou seja, um lado compensa o outro quando há cooperação entre os segmentos de qualquer economia. Além do mais, as redes de parceria e colaboração são esquemas organizacionais indispensáveis para a capacitação das micro e pequenas empresas porque as trocas de experiências permitem o crescimento das mesmas e a acumulação de conhecimentos.

Este fato é confirmado desde a era dos mercantilistas até o presente sistema capitalista. Além de criar renda e emprego, o trabalho sempre foi visto como uma fonte de geração de habilidades. Tanto que quanto maior a experiência, maior as chances de entrada no mercado de trabalho. Vale o 
mesmo para as MPEs. Ao ingressar neste ambiente, os negócios deste porte conseguem gerar renda para satisfazer necessidades, sejam estas de primeiro grau como moradia, alimentação e vestimento ou de segundo grau.

Em outras palavras, as relações e formas de trabalho foram mudando com o passar dos tempos, resultando em divisões de trabalho como descreveu o Adam Smith na sua obra "As Riquezas das Nações". Umas empresas se especializando, outras desenvolvendo novos produtos e serviços e cada uma com seu ritmo de crescimento. Este modelo estabeleu diferenças entre os empreendimentos: as grandes, médias, pequenas, e micro empresas. Com esta divisão, é possível identificar a atuação de cada grupo e aplicar benefícios e incentivos aos que precisam para aumentar as suas produções. Segundo Banterli e Monolescu (2007, p. 1),

\begin{abstract}
"A adoção de critérios para a definição de tamanho de empresa constitui importante fator de apoio às micro e pequenas empresas, permitindo que as firmas classificadas dentro dos limites estabelecidos possam usufruir os benefícios e incentivos previstos nas legislações que dispõem sobre tratamento diferenciado ao segmento"
\end{abstract}

Segundo dados do SEBRAE (2006), o tamanho das empresas brasileiras é definido pelo número de empregados, como ilustra a Tabela 1.

Tabela 1 - Classificação das microempresas por número de empregados

\begin{tabular}{|c|c|c|}
\hline Porte / Setor & Indústria & Comércio e Serviços \\
\hline Microempresas & Até 19 & Até 9 empregados \\
\hline Pequeno porte & De 20 a 99 & De 10 a 49 \\
\hline Médias & De 100 a 499 & De 50 a 99 \\
\hline Grandes & 500 ou mais & 100 ou mais \\
\hline
\end{tabular}

Fonte: Sebrae/2006

No âmbito das publicações internacionais, os estudos indicam que a criação, o papel, o desenvolvimento e as performances das micro e pequenas empresas (MPEs) têm um impacto decisivo sobre o crescimento econômico em longo prazo das mesmas e da localidade na qual se inserem. Elas são responsáveis pela difusão de novos produtos, de novas tecnologias e serviços e no contexto organizacional, elas são consideradas mais ágeis, flexíveis e 
inovadoras. Sua estrutura é vantajosa devido à sua capacidade de rápida reação às novas demandas do mercado. Quando dados os recursos e treinamento, elas conseguem aproveitar oportunidades de crescimento. Além da comunicação interna informal e eficiente, a administração participativa influencia o processo decisório. Este comportamento facilita a adaptação dos membros da organização às mudanças tanto no âmbito externo quanto interno. Além do mais, os pequenos negócios têm fundamental importância política e econômica para o país, tanto na geração de empregos, quanto de renda. Azevedo e Vinicius (1999, p.27) apud Preisler (2003) concordam dizendo que as empresas deste segmento

São relevantes do ponto de vista político, porque as micro e pequenas empresas funcionam como fator de equilíbrio da estrutura empresarial brasileira, em sua imensa maioria coexistindo com as grandes empresas; do econômico, porque o grande número de empregos que oferecem contribuem muito para a geração de receitas e a produção de bens.

A atuação das MPEs não data de hoje. A segunda guerra mundial foi um período de grande tumulto e abalo nas economias nacionais, fato este que deixou vários cidadãos desempregados. Não fosse pela participação dos micro negócios, teria sido difícil relançar o desenvolvimento econômico de várias nações que, hoje, estão entre as grandes potências do século XXI. Segundo Rattner (1985, p. 19) apud Preisler (2003):

Em 1985 as pequenas e médias empresas já constituíam a imensa maioria das empresas industriais e de serviços, responsáveis por significativa fatia dos empregos gerados, salários pagos e impostos recolhidos apesar da elevada expansão das grandes unidades produtivas nos países em desenvolvimento.

Ainda enfatizando a questão do papel das MPEs, Domingos (1995, p. 43) apud Preisler (2003) afirma que:

Nos países desenvolvidos, empresas de pequeno porte também desempenham papel significativo: nos Estados Unidos, representam $90 \%$ do universo e são responsáveis por $50 \%$ dos empregos gerados; na Comunidade Européia a avaliação é de que 92\% das empresas estejam inseridas nesse grupo; no Japão, $98 \%$ do setor constituem pequenas e médias empresas. 
De um modo geral, este setor da economia é complementar no sentido de que este segmento pode preencher as lacunas deixadas pelas grandes empresas ao produzir em massa. A abertura de mercado deu inicio também ao conceito de terceirização. É uma prática vantajosa tanto para as grandes empresas, quanto para as MPEs. Segundo Amaro e Paiva (2002, p. 8),

As pequenas firmas crescem graças à terceirização, especialmente no setor de serviços, e também pelo fato de se tornarem mais competitivas em relação às grandes empresas, em vista da maior flexibilidade. Destacam-se os nichos tecnológicos, unidades produtoras enxutas e flexíveis, que, ao lado do crescente movimento de terceirização, apontam que os grandes empregadores do futuro tendem a ser as empresas de menor porte.

Além do mais, os empregos e renda gerados influenciam o PIB (Produto Interno Bruto) de um país, proporcionando assim ganhos reais e significativos nos balanços nacionais. Segundo dados do SEBRAE (2006), esse segmento empresarial é responsável por 30\% do Produto Interno Bruto, pela criação de 14 milhões de empregos em 98,5 \% de empresas existentes no Brasil sendo 56,3\% no setor comercial, $31,9 \%$ no setor de serviços, e 11,2\% no setor de indústria. As exportações também tiveram um crescimento de $20 \%$ em 2006 , aumentando a demanda mundial por produtos brasileiros e acréscimo nos preços internacionais das comodities (SEBRAE, 2006).

Em contrapartida, as micro e pequenas empresas, quando mal chegam aos 2 anos de existência, declaram falência devido à falta de recursos para financiar projetos ou resolver situações de extrema urgência relativas a suas atividades fins. As taxas de mortalidade das MPEs permanecem altas, sendo que $29 \%$ das novas empresas encerram suas atividades antes de completar 1 ano de atividade e 56\% fecham em 5 anos de abertura (SEBRAE, 2006). Ou seja, mais uma razão que ressalta a importância de uma maior abertura do mercado de crédito. A Tabela 2 ilustra bem o exposto nesta parte da pesquisa. 
Tabela 2 - Motivos alegados pelas MPEs encerradas em 2006

\begin{tabular}{|l|c|}
\hline Falta de Capital (inicial ou de giro) & $25 \%$ \\
\hline Inadimplência & $19 \%$ \\
\hline Problemas de Planejamento & $11 \%$ \\
\hline Problemas Particulares & $11 \%$ \\
\hline Problemas Legais & $7 \%$ \\
\hline Concorrência Forte & $6 \%$ \\
\hline Perda de Clientes & $4 \%$ \\
\hline Elevadas Taxas de Juros & $2 \%$ \\
\hline
\end{tabular}

Fonte: Sebrae/2006 com adaptação

\subsection{Gestão bancária}

Em geral, os bancos tradicionais (comerciais e múltiplos) são os instrumentos da intermediação financeira que vai dos agentes que têm recursos para depositar com direito à recompensa em formas de taxas de juros até os que necessitam para investimentos aplicados também à taxas de juros, mas como custo adicional. Esta intermediação é segmentada com base em quatro mercados que compõem o mercado financeiro: monetário, de crédito, de capitais e cambial. Este trabalho se limita ao mercado de crédito que, segundo Assaf Neto (2001, p. 62) "visa fundamentalmente suprir as necessidades de caixa de curto prazo e médio prazo dos vários agentes econômicos, seja por meio da concessão de créditos às pessoas físicas, seja por empréstimos e financiamentos às empresas".

\subsubsection{Mercado de crédito}

O instrumento usado para efetuar as transações neste mercado é a moeda ou o crédito, definido como o meio universal de troca que tem uma função social muito importante: financiar o consumo. Com este produto financeiro, aumenta-se o poder aquisitivo dos clientes. Silva (2004, p. 68) afirma que

"o crédito, sem dúvida, cumpre importante papel econômico e social, a saber: (a) possibilita às empresas aumentarem seu nível de atividade; (b) estimula o 
consumo influenciado na demanda; (c) ajuda as pessoas a obterem moradia, bens e até alimentos; e (d) facilita a execução de projetos para os quais as empresas não disponham de recursos próprios suficientes."

Este mercado funciona de maneira muito similar aos demais: um aumento na quantidade de moeda no mercado significa redução de seu preço, ou seja, faz com que ela diminua seu poder de compra. Como dito anteriormente neste capitúlo, são aplicadas taxas de juros.

\subsubsection{Taxas de juros}

De acordo com Casarotto Filho e Kopittke (2000, p.18), "os fatores de produção considerados em economia - trabalho, terra, capacidade administrativa, técnica e capital - são remunerados cada um de uma forma". Ou seja, o juro é uma taxa adicional acrescentada para se adquirir o capital durante um determinado período, servindo de remuneração e lucro para as instituições bancárias. Este lucro é chamado de spread que pode ser definido como a diferença entre a taxa de aplicação e a taxa de captação de recursos financeiros, ou seja, é a diferença entre os juros cobrados pelos bancos nos empréstimos a pessoas físicas e jurídicas e as taxas pagas pelos bancos aos investidores que colocam seu dinheiro em aplicações do banco. Quanto maior o spread bancário, maior é o lucro que os bancos têm nas operações de crédito.

Segundo dados do Banco Central (2002),

o spread se decompõe em diversas parcelas: impostos diretos (20,6\%); impostos indiretos e contribuições ao Fundo Garantidor de Créditos (7,9\%); despesas administrativas (14,1\%); despesas com inadimplência (17\%); e margem líquida $(40,1 \%)$. A margem líquida compreende não apenas o lucro da instituição, mas também a compensação por créditos de direcionamento obrigatório e despesas não-operacionais.

Ao pedir um empréstimo, os bancos aplicam uma taxa de juros que é proporcional ao valor, o prazo, os riscos, a demanda e oferta de moeda entre outros fatores. De acordo com Stiglitz e Weiss (1981) apud Nitsch (2001, p. 175) "na tentativa de evitar um deterioramento da qualidade de sua carteira de crédito, os bancos estabelecem, voluntariamente, limites para taxa de juros e, com isto, racionam a oferta de crédito". Além do mais, as politícas monetárias influenciam bastante a variação deste conceito, ou seja, se a relação moeda em 
relação ao PIB (Produto Interno Bruto) for muito grande, os juros tendem a cair e os preços a subir, e se for muito pequena a tendência é oposta (ASSAF NETO, 2001). Mas quando se trata das MPEs, este cálculo varia também de acordo com as garantias e documentação disponíveis sujeitas à análises, tema da próxima seção.

\subsection{Análise de risco de crédito}

O enfoque do crédito nesta pesquisa é de natureza bancária e segundo Schrickel (1995, p. 25) apud Preisler (2003), este pode ser definido como:

Todo ato de vontade, ou disposicão de alguém destacar ou ceder, temporariamente, parte de seu patrimônio a um terceiro, com a expectativa de que essa parcela volte a sua posse integralmente, após decorrido o tempo estipulado.

Esta atividade é desenvolvida formalmente pelas instituições financeiras que aplicam encargos financeiros e taxas de juros que podem compensar o risco da promessa de pagamento que pode não ser cumprida, devido a alguns fatores como a falência, recessão, inviabilidade do negócio ou falta de confiança no cliente. Portanto, a previsão da capacidade de pagamento ou a competência empresarial do cliente é reduzida, criando incertezas e riscos elevados demais para as instituições financeiras. A análise em si consiste em avaliar com o intuito de achar respostas ou soluções a questionamentos em torno de uma decisão. Esta tarefa dos agentes bancários pode parecer bem simples, mas quando se trata de concessão ou não de crédito, é preciso fazer mais do que isso, ou seja, no que diz respeito às MPEs a questão do risco é ainda mais complexa.

Averiguação de informações cadastrais do cliente e da empresa, dados e cálculos quantitativos e qualitativos de índices, observação de flutuações mercadológicas e aplicação de técnicas estatísticas são algumas das tarefas desenvolvidas pelos especialistas de crédito no momento da aprovação ou não do empréstimo. Segundo Schrickel (1995, p. 26 e 27) apud Preisler (2003),

A concessão de empréstimo envolve três etapas:

- análise retrospectiva, que se refere à avaliação do desempenho histórico do tomador e de sua atividade; 
- análise de tendências, com a projeção da condição financeira futura do tomador e sua capacidade de endividamento;

- capacidade creditícia, etapa na qual é avaliada a proposta de crédito estruturada com previsão de amortização da dívida.

Mas, infelizmente, muitas Instituições Financeiras (IFs) utilizam as mesmas ferramentas tanto para grandes empresas quanto para MPEs. Figueiredo (2001, p. 99) apud Preisler (2003) concorda ao dizer que

As técnicas de análise para investimentos ou concessão de crédito foram desenvolvidas com base em parâmetros adequados às grandes empresas e acabam, no geral, sendo utilizados para avaliar solicitações de empresas menores.

O objetivo da maioria das IFs, como qualquer empresa, é ter mais retorno do que prejuízo, sendo que nas situações de empréstimos, o risco e o retorno funcionam lado a lado em operações bancárias. Geralmente, o risco deve ser compatível com o nível aceito pelo banco e do posicionamento da mesma no mercado. De acordo com Gitman (1984, p. 13) apud Preisler (2003),

Uma premissa básica na administração financeira é que existe uma relação entre risco e retorno: os acionistas esperam receber maiores retornos de investimentos de maior risco e vice-versa.

O mesmo se aplica aos bancos, ou seja, quanto mais retorno, melhor ainda. Mas para isso, são necessárias avaliações capazes de mensurar o risco involvido para obter uma melhor decisão relativa à concessão de crédito. Santi Filho (1997, p. 15) apud Preisler (2003) afirma que

[...] a avaliação do caráter do tomador de crédito integra o que é chamado risco técnico. Conceituado como risco, pois é passível de verificação quanto às probabilidades objetivas de estimação, em contraposição à incerteza que ocorre quando não existem dados históricos acerca do tomador. É técnico, à medida que as fontes disponíveis de informação podem ser pesquisadas e o resultado apresentado indicará, com bastante segurança, o que se pretende avaliar [...]. Nos dados cadastrais do cliente devem constar, além da identificação, pontualidade, existência de restrições, dados referentes à experiência em negócios e a atuação na praça, ou seja, tradição e relacionamento com a comunidade.

No processo decisório de crédito, existem muitas incertezas que devem ser ponderadas antes de se passar para as próximas etapas. Schrickel apud Preisler (2003) ressalta ainda que 
Risco significa incerteza, imponderável, imprevisível, e estes, a incerteza, a imponderabilidade e imprevisibilidade situam se necessária e unicamente, no futuro. Assim, embora a análise de crédito deva lidar com eventos passados do tomador de empréstimos (a análise histórica), as decisões de crédito devem considerar primordialmente o futuro desse mesmo tomador.

Deste modo, o gerenciamento de risco é o resultado de um conjunto de politícas de risco de crédito alinhado com os níveis de risco que a IF normalmente assume. Um banco deve gerenciar suas operações adequadamente para manter seu equilíbrio que, posteriormente, induzirá em um aumento na rentabilidade. Conforme Silva (2004), "politícas são instrumentos que determinam padrões de decisão para resolução de problemas semelhantes". Assim sendo, as instituições financeiras dependem de uma boa gestão do risco de crédito, o que é efetuado parcialmente por meio de informações a respeito do cliente. A concessão de crédito é geralmente possivel apenas para aqueles que se enquadrem dentro dos limites de risco que a instituição financeira pode assumir segundo sua política de crédito que, se mal aplicada, pode significar a rentabilidade ou falência do banco, já que ao adquirir os recursos, ele se torna devedor.

\subsubsection{Tipos de risco}

A questão do risco começou a ser enfatizada com mais rigor depois que uma série de bancos tradicionais como a Barings Bank, Procter\&Gamble, Bankers Trust e a Orange County estavam na mira da falência, já que estes ligavam o risco somente a derivativos para fins de alavancagem para aumentar o risco e para fins de hedge com o objetivo de diminuir o risco (DUARTE, 1993).

Existem vários tipos de risco que influenciam as operações de crédito. Para ser mais especifíco, são quatro tipos: risco de mercado, risco operacional, risco de crédito e risco legal. Cada um influencia os agentes econômicos de modo diferente, dependendo das situações.

O primeiro, o risco de mercado, além de depender de como o preço de um ativo reage frente às condições de mercado e volatilidades e correlações dos fatores que o influenciam, pode ser dividido ainda em quatro grupos: risco do 
mercado acionário, risco do mercado de câmbio, risco do mercado de juros e risco do mercado de commodities.

O segundo, o risco operacional, trata das perdas decorrentes de falhas de gerenciamento e no controle das operações. Este risco é também divido, mas em três subgrupos:

- o risco organizacional que diz respeito à ineficiência na administração e controle de uma empresa;

- o risco de operações que decorre dos problemas relacionados à má execução das atividades e/ou utilização dos recursos; e

- o risco de pessoal que está relacionado aos empregados (qualificação, motivação, personalidade etc).

O terceiro, o risco de crédito, se aplica bastante a esta pesquisa. É geralmente analisado pelos bancos, já que diz respeito às possíveis perdas que podem ocorrer caso um cliente não cumpre suas promessas assumidas. Este risco é também dividos em três subgrupos:

- O risco do país em relação a outros;

- O risco político quando são aplicadas restrições ao fluxo livre de capitais entre os agentes que compõem o sistema financeiro tanto nacional quanto internacional; e

- O risco da falta de pagamento que é basicamente a possibilidade um cliente não poder mais cumprir promessas de pagamento de dívida.

O último, o risco legal, está relacionado à impossibilidade de se resgatar um contrato legalmente amparado que gerou perdas significativas para a empresa/banco (DUARTE, 1993). A Figura 1 resume os riscos identificados que mais influenciam uma decisão de concessão de crédito ou não no gerenciamento de risco. 
Figura 1 - Os quatro grandes grupos de risco

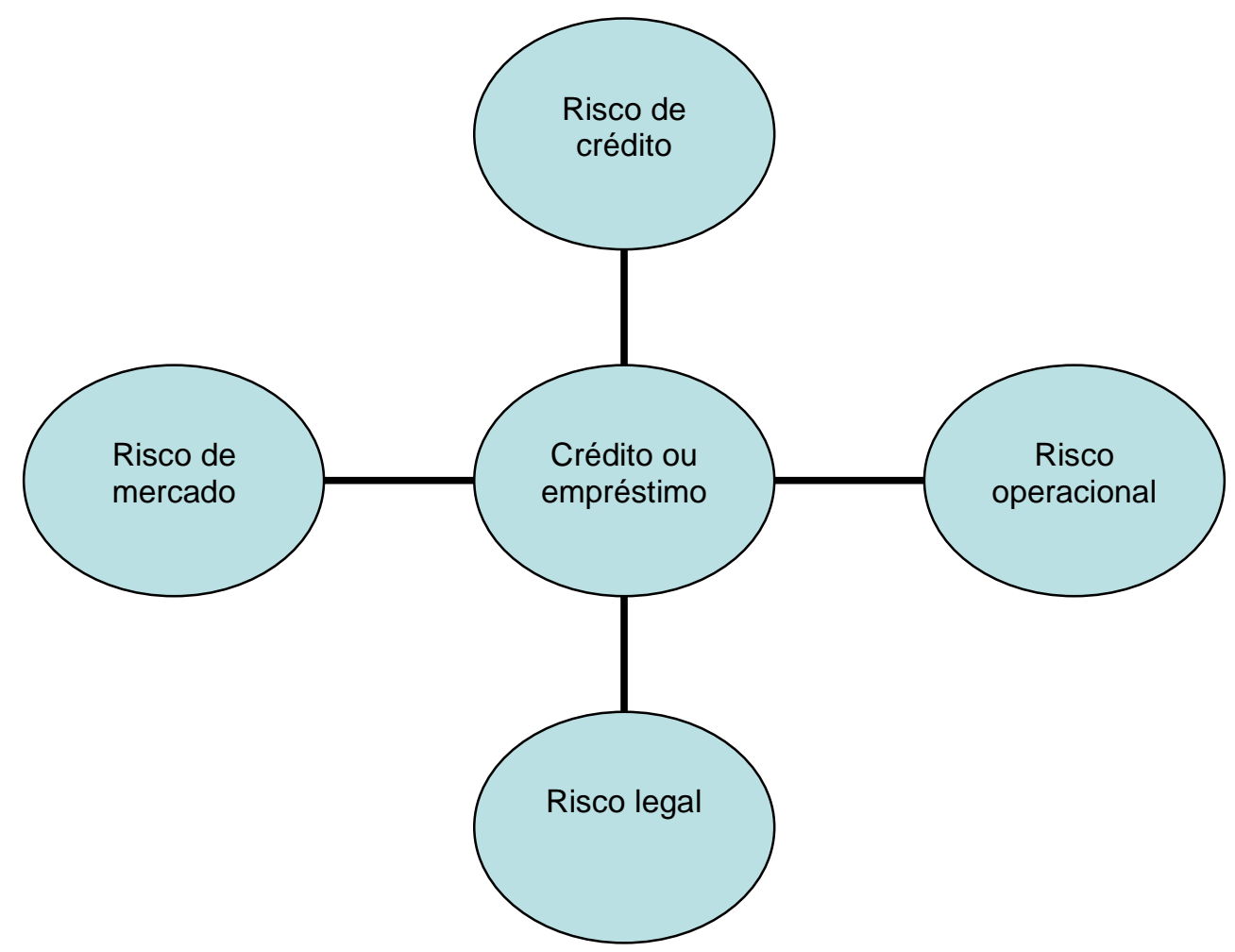

Fonte: Elaboração do autor

O risco de crédito de uma operação de financiamento é o aspecto que influencia mais a decisão de concessão e que é sujeito a várias análises que variam de acordo com o banco. Segundo Relatórios Bancários da Caixa Econômica Federal, a alta gerência é responsável pelo estabelecimento de normas e prazos de captação e aplicação de recursos, taxas de juros, garantias e os métodos de análise de risco em cada tipo de operações. No caso das operações de crédito, o método mais empregado pela maioria das instituições financeiras é baseado nos "Cs", do crédito, tema da próxima seção.

Sendo um dos elementos chave desta pesquisa, o crédito pode ser considerado como "o salva-vida" de empresas em falência ou das que desejam crescer, atingir outro patamar e até começar a atuar no mercado internacional, objetivo este que é de influencia positiva nos balanços nacionais. Para tanto, as MPEs precisam elaborar um plano de negócios que deve ser formalizado e 
alinhado com sua missão e visão de futuro. O mesmo acontece com as instituições financeiras ao analisarem o perfil de um potencial cliente. De acordo com Silva (2004, p. 91),

A formalização do acordo de crédito por meio de um contrato bem elaborado é uma condição fundamental para assegurar ao credor o direito de receber, independente da vontade do devedor de pagar.

Os contratos geralmente contêm os dados pessoais do cliente e as informações jurídicas do presente ou futuro empreendimento/projeto. Silva (2004, p. 91) completa ao dizer que

O analista, ao examinar uma proposta de crédito, estará atento às diversas variáveis relacionadas ao risco do cliente e da operação. Estará buscando informações relativas ao passado do cliente, ao presente (viabilidade de seu empreendimento e outros dados relevantes) e ao futuro quanto a capacidade de pagamento.

Em resumo, vale ressaltar que o empréstimo só é concedido quanto os índices apresentarem valores positivos, ou seja, viabilidade e rentabilidade para ambas as partes da operação. Hoje em dia, essas análises de viabilidade são feitas com mais precisão devido o uso de sistemas automatizados. A evolução da tecnologia permite aos bancos avaliarem as propostas com mais precisão, contando que sejam feitos os devidos inputs de dados a respeito do solicitante. A seção a seguir apresenta os elementos que estão relacionados ao cliente e sua proposta.

\subsubsection{Processo analítico: C's do crédito}

Os C's do crédito analisam alguns apectos relativos ao requerente de empréstimo. Devido a falta de garantias reais, as MPEs são sujeitas a esta avaliação pelos bancos que têm a intenção de obter mais informações que possam servir de subsídios para a redução de risco. A partir da ficha cadastral preenchida no ato do pedido e da qual é feita a formalização do contrato, uma análise técnica é gerada junto com as seguintes variáveis:

- Caráter, item no qual é observada a intenção de pagar; 
- Capacidade, que se refere à competência empresarial do cliente;

- Condições, que englobam os fatores externos e macroeconômicos (oportunidades e/ou ameaças) que influenciam diretamente o cliente e seu negócio;

- Colateral, que implica a avaliação das garantias reais para contrabalançar os resultados negativos e;

- Capital, quando o cliente possui outros recursos financeiros para dar partida ao negócio e/ou ao seu crescimento.

Silva (2004, p. 91) afirma que

Um bom sistema de classificação de risco é fundamental para a decisão de crédito, orientando quanto ao nível de risco que esta sendo assumido, quanto às expectativas de inadimplência, bem como ao grau de exigência de garantias. Também será fundamental para determinar a periodicidade das revisões de crédito.

A análise técnica das variáveis listadas possibilita o dimensionamento do efetivo risco de crédito e assim, a classificação das situações das empresas e/ou clientes antes de chegar a decisão de concessão de crédito. Depois deste processo, alguns empreendimentos são aprovados mas as taxas de juros não deixam de ser acrescentadas como custo de operação. Apesar da tentativa de redução dos juros, alguns bancos não podem passar dos limites préestabelecidos em cada serviço de seu portfólio. Mas para a grande maioria das MPEs, as taxas continuam altas demais e incompatíveis com sua realidade e capacidade de pagamento. Sendo assim, as microfinanças procuram estabelecer um equilíbrio entre os objetivos de ambas partes de um pedido de financiamento.

\subsection{Conceituação das microfinanças}

As desigualdes no ambito social, do trabalho, da educação, entre outros sempre acompanharam a evolução das sociedades, mas com consequências e 
mudanças diferentes na busca de redução destas diferenças. As microfinanças têm este mesmo propósito.

A atuação desta ferramenta começou com o microcrédito, que é basicamente um empréstimo de pequeno valor em dinheiro sujeitos a taxas de juros. Mas com o decorrer do tempo, foram se acrescentando outros serviços para transformar o microcrédito em uma atividade mais completa que agregue mais valor tanto para o banco quanto para o requisitante de empréstimo. Para evitar a dependência dos clientes, criou-se um sistema que permite transformar simples pessoas em empreendedores, dando-lhes os insumos e as condições básicas para que desenvolvam comportamentos ou aperfeiçoam habilidades essenciais para geração de renda.

Essas modificações deram início às microfinanças que, além de ofertar microcréditos, disponibiliza serviços de poupança programada, seguro, acompagnamento bancário, treinamento, entre outros à um custo acessível para os clientes e lucrativo para as IMFs que trabalham no ramo.

Segundo o Portal de Microcrédito, esta inovadora ferramenta é, de uma forma geral, qualquer operação de natureza financeira destinada a clientes de baixa renda, incluindo trabalhadores autónomos. De acordo com Martins (2002, p. 60), a legislação brasileira define as microfinanças como "a concessão de financiamentos a pessoas físicas e microempresas, com vistas à viabilização de empreendimentos de natureza profissional, comercial ou industrial, de pequeno porte".

As instituições que operem com esta ferramenta são de natureza civil, ou seja não comercial, sem fins lucrativos e suas carteiras são compostas de empréstimos de pequeno valor. Devido a essas características, elas não são cadastradas nos registros de comércio e das autoridades monetárias e de controle público. Todavia, elas possuem registro próprio em cartórios de registro civil de pessoas jurídicas ou no Ministério da Justiça (MARTINS, 2002).

Em relação a seus objetivos-fins, Martins (2002, p. 59) explica que o Banco Mundial afirma que as instituições de Microfinanças se empenhem em: 
a) oferecer pequenos empréstimos, tipicamente para capital de giro;

b) fazer análise de crédito informal;

c) oferecer alternativas à apresentação de bens em garantia, tais como grupos de garantia solidária ou mecanismos de poupança compulsória;

d) dar acesso contínuo a empréstimos de valor crescente com base no histórico de pagamento;

e) utilizar formas simplificadas de concessão e acompanhamento de empréstimos;

f) oferecer formas seguras de poupança.

O Quadro 2 a seguir apresenta outras definições de acordo com os organismos abaixo listados.

Quadro 2 - Definições de microfinanças e microcrédito

\begin{tabular}{|c|c|c|}
\hline Fonte & Microfinanças & Microcrédito \\
\hline BID & & $\begin{array}{l}\text { Empréstimo de pequeno valor } \\
\text { Concedido em larga escala } \\
\text { Para pessoas e empresas }\end{array}$ \\
\hline Banco Mundial & $\begin{array}{l}\text { Empréstimo de pequeno valor } \\
\text { Garantias não tradicionais } \\
\text { Empréstimos contínuos e } \\
\text { crescentes } \\
\text { Metodologias simplificadas de } \\
\text { análise, concessão e } \\
\text { acompanhamento de crédito } \\
\text { Formas seguras de poupança }\end{array}$ & \\
\hline BNDES & $\begin{array}{l}\text { Serviços financeiros, como } \\
\text { crédito, poupança e seguros } \\
\text { Para pessoas e empresas } \\
\text { de baixa renda }\end{array}$ & \\
\hline Legislação brasileira & & $\begin{array}{l}\text { Empréstimos [de pequeno } \\
\text { valor] } \\
\text { Para pessoas e empresas } \\
\text { Com fins empresariais ou } \\
\text { profissionais }\end{array}$ \\
\hline
\end{tabular}

Fonte: Martins (2002, p. 60)

Em questão de atuação no ramo das microfinanças, somente algumas entidades têm a autorização. Martins (2002, p. 71), explica que no caso 
brasileiro, esta atividade pode ser desenvolvida por instituições financeiras stricto sensu como os bancos de desenvolvimento, comerciais, financeiras, SCMs e cooperativas de crédito. O Quadro 3 resume este fato não somente no Brasil, mas em outros países da América Latina.

Quadro 3 - Entidades especializadas em microfinanças e suas características

\begin{tabular}{|c|c|c|c|c|}
\hline País & Nome & $\begin{array}{l}\text { Ano de } \\
\text { criação }\end{array}$ & Forma jurídica & Proprietários \\
\hline Brasil & $\begin{array}{l}\text { Soc. de Crédito ao } \\
\text { Microempreendedor (SCM) }\end{array}$ & 2001 & $\begin{array}{c}\text { Cia. de } \\
\text { responsabilidade } \\
\text { limitada ou soc. } \\
\text { anônimas de capital } \\
\text { fechado }\end{array}$ & $\begin{array}{c}\text { OSCIPS, pessoas físicas } \\
\text { ou jurídicas }\end{array}$ \\
\hline Bolívia & $\begin{array}{l}\text { Fundos Financeiros Privados } \\
\text { (FFP) }\end{array}$ & 1995 & Soc. anônimas & $\begin{array}{c}\text { ONGs, pessoas físicas } \\
\text { ou jurídicas }\end{array}$ \\
\hline El Salvador & $\begin{array}{l}\text { Soc. de Poupança e Crédito } \\
\text { (SAC) }\end{array}$ & 2000 & Soc. anônimas & $\begin{array}{c}\text { Pessoas físicas ou } \\
\text { jurídicas }\end{array}$ \\
\hline \multirow{3}{*}{ Peru } & $\begin{array}{c}\text { Caixas Municipais de } \\
\text { Poupanca e Crédito (CMAC) }\end{array}$ & 1980 & Empresas municipais & Prefeituras \\
\hline & $\begin{array}{l}\text { Caixas Rurais de Poupança e } \\
\text { Crédito (CRAC) }\end{array}$ & 1992 & Soc. anônimas & $\begin{array}{l}\text { Pessoas físicas ou } \\
\text { jurídicas }\end{array}$ \\
\hline & $\begin{array}{l}\text { Entidades de } \\
\text { Desenvolvimento da } \\
\text { Pequena e Microempresas } \\
\text { (EDPYME) }\end{array}$ & 1994 & Soc. anônimas & $\begin{array}{c}\text { ONGs, pessoas físicas } \\
\text { ou jurídicas }\end{array}$ \\
\hline Panamá & $\begin{array}{l}\text { Bancos de Microfinanças } \\
\text { (BMF) }\end{array}$ & 2001 & Soc. anônimas & $\begin{array}{c}\text { As mesmas pessoas } \\
\text { que podem ser } \\
\text { acionistas de um banco }\end{array}$ \\
\hline Venezuela & $\begin{array}{c}\text { Bancos Especializados em } \\
\text { Microcrédito (BEM) }\end{array}$ & 2000 & Soc. anônimas & $\begin{array}{c}\text { Pessoas físicas ou } \\
\text { jurídicas, prefeituras, } \\
\text { bancos, Estado }\end{array}$ \\
\hline
\end{tabular}

Fonte: R. Rosales (2002, p. 28) apud Martins (2002, p. 66)

Os dois tipos de bancos apresentam algumas similaridades. Ambas avaliam a situação particular de cada cliente, as condições do empréstimo e viabilidade econômica da atividade a ser empreendida, além do panorama geral da economia. Porém possuem focos e critérios diferentes que requerem procedimentos adequados às politicas adotadas nas operações. Uma dessas políticas é o fornecimento de garantias. 


\subsubsection{Garantias}

O dicionário brasileiro GLOBO (2003) define garantia como "a ação de garantir aquilo que se vendeu, tratou ou convencionou". O devedor e o credor chegam a um consenso para que ninguém acabe no prejuizo total, caso houver geração de dívida.

Os bancos tradicionais exigem garantias reais em forma de patrimônio ou bens materiais que servem de penhor, visto que o risco é muito alto. A falta de garantias formais como documentos contábeis, declarações de renda e de bens materiais impossiblita 0 acesso das MPEs às linhas de crédito tradicional. Felizmente, as microfinanças são flexíveis e se adaptam à demanda de sua clientela para reduzir as situações de assimetria de informações e de inadimplência. Um dos bancos especializados em operações microfinanceiras é o Grameen Bank em Bangladesh.

O sucesso do banco se deve ao modelo implantado como estratégia para atrair maior clientela com baixos juros: crédito em grupo ou solidário. É geralmente usado nas regiões rurais onde todos se conhecem bem dentro da comunidade. Segundo Nitsch (2001, p. 176), o modelo envolve as seguintes etapas:

- Identificação dos membros potenciais;

- Participação dos escolhidos em um curso ou treinamento de no máximo duas semanas;

- Transmissão de princípios e padrões de comportamento aceitáveis, com o intuito de conscientizar os participantes e;

- Seleção e composição dos grupos de crédito.

Feita a seleção, Nitsch (2001, p. 177) afirma ainda que o Grameen Bank explica os termos da solicitação de crédito para cada membro e "o próprio grupo torna-se responsável, portanto, pelo monitoramento da aplicação e pagamento dos empréstimos" por meio da utilização do peer monitoring e peer pressure. Ou seja, os membros se controlam e se pressionam para fazer bom uso dos recursos e efetuar os pagamentos em dia para não perder o direito de fazer novos empréstimos. Deste modo o banco controla e regula indiretamente o 
comportamento dos membros com intuito de reduzir os riscos e custos. As garantias não são os únicos aspectos que variam do sistema bancário convencional. O Quadro 4 apresenta algumas diferenças entre os bancos tradicionais e as instituições autorizadas a operar com as microfinanças.

Quadro 4 - Diferenças entre IFCs e IMFs

\begin{tabular}{|c|c|c|}
\hline Categoria & IFCs & IMFs \\
\hline $\begin{array}{l}\text { Metodologia de } \\
\text { crédito }\end{array}$ & $\begin{array}{l}\text { (1) Baseada em garantias reais } \\
\text { (2) Muita documentação } \\
\text { (3) Menos intensiva em recursos } \\
\text { humanos }\end{array}$ & $\begin{array}{l}\text { (1) Baseada no caráter do devedor } \\
\text { (2) Pouca documentação } \\
\text { (3) Mais intensiva em recursos } \\
\text { humanos }\end{array}$ \\
\hline $\begin{array}{l}\text { Carteira de } \\
\text { empréstimos }\end{array}$ & $\begin{array}{l}\text { (1) Maior quantidade } \\
\text { (2) Maior valor médio } \\
\text { (3) Com garantias reais } \\
\text { (4) Prazo médio longo } \\
\text { (5) Taxa de inadimplência mais estável }\end{array}$ & $\begin{array}{l}\text { (1) Menor quantidade } \\
\text { (2) Menor valor médio } \\
\text { (3) Sem garantias reais } \\
\text { (4) Prazo médio curto } \\
\text { (5) Taxa de inadimplência mais volátil }\end{array}$ \\
\hline Carteira de clientes & $\begin{array}{l}\text { (1) Maior quantidade } \\
\text { (2) Empresas formais e pessoas } \\
\text { formalmente empregadas } \\
\text { (3) Dispersão geográfica }\end{array}$ & $\begin{array}{l}\text { (1) Menor quantidade } \\
\text { (2) Empresas informais e pessoas } \\
\text { informalmente empregadas de baixa } \\
\text { renda } \\
\text { (3) Concentração geográfica }\end{array}$ \\
\hline Estrutura societária & $\begin{array}{l}\text { (1) Acionistas individuais e institucionais } \\
\text { interessados na maximização de } \\
\text { resultados } \\
\text { (2) Em geral criadas a partir de outras } \\
\text { IFCS } \\
\text { (3) Organização centralizada com } \\
\text { agências preferencialmente localizadas } \\
\text { em áreas urbanas }\end{array}$ & $\begin{array}{l}\text { (1) Principalmente acionistas } \\
\text { institucionais sem fins lucrativos } \\
\text { (2) Em geral criadas a partir de ONGs } \\
\text { (3) Grupo descentralizado de } \\
\text { pequenas unidades freqüentemente } \\
\text { localizadas em áreas com pequena } \\
\text { infra-estrutura urbana }\end{array}$ \\
\hline
\end{tabular}

Fontes: T. Jansson e M. Wenner (1997, p. 9) e T. Jansson (2001, p. 9) apud Martins (2002, p. 63) 


\section{MÉTODOS E TÉCNICAS DE PESQUISA}

Este capítulo apresenta os tipos de pesquisa e os instrumentos de pesquisa utilizados para a definição da população, coleta de dados e análise das informações obtidas durante as investigações.

\subsection{Delineamento da pesquisa}

A abordagem de uma pesquisa pode ser classificada em estudo em quantitativo ou qualitativo. O primeiro considera que tudo pode ser quantificável, o que significa traduzir em números opiniões e informações para classificá-las e analisá-las. E o segundo é um método descritivo que se caracteriza pela não utilização de técnicas estatísticas, tendo o ambiente natural como fonte de informações quando são devidamente aplicados os intrumentos de coleta de dados.

$\mathrm{Na}$ pesquisa a ser realizada neste estudo, a qualitativa se enquadra melhor, visto que Markoni e Lakatos (2002) consideram que há uma relação dinâmica entre o mundo real e o sujeito, isto é, um vínculo indissociável entre o mundo objetivo e a subjetividade do sujeito que não pode ser demonstrada em números. A interpretação dos fenômenos e a atribuição de significados são básicas no processo de pesquisa qualitativa. Neste caso, o ambiente natural é a fonte direta para coleta de dados e o pesquisador se apropria deste ambiente para se familiarizar com o tema em questão, e assim, chegar a conclusões. $O$ pesquisador tende a analisar seus dados indutivamente com base em fatos reais e dados obtidos por meio de revisões bibliográficas e pesquisa de campo para que os resultados expressem a realidade do problema em questão.

O estudo do qual se trata este trabalho é também de natureza descritiva, pois se propõe em analisar e descrever as características, elementos e fatores influenciadores das microfinanças como solução prática ao desenvolvimento das Micro e Pequenas Empresas e, conseqüentemente, das economias nacionais. A pesquisa pode também ser considerada de caráter exploratório dado que se busca conhecer um fenômeno sobre o qual existem poucas observações. 
Envolve levantamento bibliográfico; entrevistas com pessoas que tiveram ou ainda têm experiências práticas com o problema pesquisado. Neste caso, os entrevistados são gerentes de empresas deste segmento e um analista de crédito da Caixa Econômica Federal.

Marconi e Lakatos (2002, p. 18) afirmam que:

"O investigador, baseando-se em conhecimentos teóricos anteriores, planeja cuidadosamente o método a ser utilizado, formula problema e hipóteses, registra sistematicamente os dados e os analisa com a maior exatidão possível. Para efetuar a coleta dos dados, utiliza instrumentos adequados, emprega todos os meios mecânicos possíveis, a fim de obter maior exatidão na observação humana, no registro e na comprovação de dados".

Assim, o trabalho proporcionou maior familiaridade com o problema com vistas a torná-lo explícito e/ou construir hipóteses. O risco de crédito aplicado às microfinanças no segmento das Micro e Pequenas Empresas pode ser considerado como uma atividade de crucial importância para as instituições devido às dificuldades de conceder empréstimos aos agentes deste segmento que apresentam alto risco de operação. Sendo assim, foi escolhida a pesquisa exploratória já que os dados publicados ainda são escassos. Os resultados obtidos da presente investigação serviram de base para uma melhor compreensão do problema e como subsídios com vistas a mais elaborações e estudos tendo em vista a importância da atuação das Micro e Pequenas Empresas no desenvolvimento econômico. Segundo Marconi e Lakatos (2002), na concepção de especialistas em metodologia de pesquisa, a pesquisa exploratória é recomendada em casos em que existe pouco conhecimento acumulado sobre o objeto em estudo.

Do ponto de vista da sua natureza, a pesquisa pode ser básica ou aplicada, sendo no caso deste trabalho, caracterizada como aplicada, tendo em vista que objetiva gerar conhecimentos para aplicação prática dirigidos à solução de problemas específicos, envolvendo verdades e interesses locais (MARKONI e LAKATOS, 2002). 


\subsection{Caracterização da organização}

Este trabalho é composto por dois setores. Primeiramente, são as Micro e Pequenas empresas que constituem uma grande parcela das empresas brasileiras. Elas são unidades produtivas que crescem a cada ano, mas que morrem a cada 2 anos devido às barreiras provenientes da falta de garantias reais e, consequêntemente, de financiamento. A segunda amostra é o setor bancário responsável pela disponibilização de recursos aos agentes econômicos de uma localidade. Por se tratar especificamente de serviços microfinanceiros, os principais estabelecimentos que repassam recursos às entidades autorizadas a desenvolver estas atividades, ou seja, que financiam as Micro e Pequenas Empresas são: o Banco do Brasil, o Banco Nacional de Desenvolvimento Econômico e Social (BNDES) e a Caixa Econômica Federal (CEF). Esta pesquisa de campo se baseou somente nas politícas e linhas de crédito da CEF.

A CEF é uma empresa pública do governo federal brasileiro e conta em caráter excepcional com serviços bancários autorizados pelo Conselho Monetário Nacional (CMV). Seu propósito é incentivar a poupança e conceder empréstimos sob penhor, com a garantia do governo. Esta característica diferencia a instituição de outras por dar segurança aos depositantes e cobrar juros considerados acessíveis.

De forma geral, a missão da CAIXA é promover a melhoria contínua da qualidade de vida da população brasileira, intermediando recursos e negócios financeiros, atuando no fomento ao desenvolvimento urbano e nos segmentos de habitação, saneamento e infra-estrutura, e na administração de fundos, programas e serviços de caráter social.

\subsection{População e amostra}

A pesquisa foi realizada junto a dois segmentos:

a) O setor empresarial constituído por micro e pequenos empreendedores da Feira do Guará e Feira dos Importados

b) O setor bancário constituído por analistas de crédito da Caixa Econômica Federal. 


\subsection{Caracterização dos instrumentos de pesquisa}

Para a coleta de dados da pesquisa, foram utilizadas duas técnicas. A primeira foi a análise exploratória que visou 0 aprofundamento dos conhecimentos acerca das empresas estudadas, no que diz respeito a suas dificuldades, suas caracteristícas e funções relacionadas às operações de crédito. A segunda técnica consistiu na aplicação aleatória de questionários entre 80 micro e pequenas empresas na Feira dos Importados e do Guará e um agente de crédito na Caixa Econômica do Brasil em Brasília. Foram elaborados e aplicados dois diferentes questionários tanto com perguntas objetivas quanto com perguntas abertas, aplicados respectivamente aos dois grupos (a) e (b) referidos na seção 3.3 .

\subsection{Procedimentos de coleta e de análise de dados}

Esta pesquisa teve duas etapas. A primeira se fundamentou em livros, relatórios bancários, artigos e revistas especializadas, além de dissertações e teses que tratam do tema em estudo.

Em seguida, realizou-se uma pesquisa de campo que comprova 0 exposto no trabalho. Foram aplicados dois questionários para a coleta de informações junto aos selecionados dos segmentos já identificados nos itens anteriores. O questionário 1 consistiu em obter informações junto as MPEs para saber se elas têm necessidade de linhas de crédito e se sabem onde procurar os recursos à disposição. O questionário 2 foi aplicado à Caixa Econômica por ter sido mencionada, na maioria das vezes, pelos entrevistados e pela facilidade de obtenção de informações detalhadas. O objetivo foi identificar as linhas de crédito destinadas à MPEs e fazer uma comparação dos métodos usados com as Microfinanças. Após a aplicação dos questionários, foi feita uma análise dos dados obtidos e uma descrição da situação das empresas e das linhas de crédito bancário frente aos diferentes aspectos pesquisados. Por fim, o envolvimento do pesquisador adicionado ao levantamento dos resultados possibilitou a elaboração de conclusões e propostas. 


\section{APRESENTAÇÃO E ANÁLISE DOS RESULTADOS DA PESQUISA}

O objetivo deste capítulo é apresentar e discutir os resultados do desenvolvimento da pesquisa. Em cada tópico serão apresentados os dados obtidos, sejam por meio de análise de documentação organizacional ou questionários, acompanhados de uma observação que se baseou na revisão de literatura executada para este trabalho.

\subsection{Participantes do estudo}

Na etapa exploratória da pesquisa, foram realizadas a análise documental e a aplicação de questionários. Participaram do estudo dois grupos: o primeiro foi composto de 80 micro e pequenos empresários e o segundo, de um analista de crédito da CEF.

\subsubsection{Micro e pequenas empresas}

$\mathrm{Na}$ Feira dos Importados, a análise de perfil dos empreendedores mostrou que a maioria se encaixa na faixa étaria de 30 a 50 anos. Os entrevistados apresentaram renda variável na faixa de $R \$ 300$ a $R \$ 50.000$ com as depesas operacionais inbutidas como por exemplo despesas de salário, fornecedores, frete, armazenagem, aluguel, entre outros. Os empreendimentos eram de micro e pequeno porte no setor de comércio e serviços. Eles variavam entre engraxateiros, vendedores ambulantes de bebidas, doces e comida, comércios fixos de produtos cosméticos, tecnológicos, de varejo, de antiguidades, móveis, tecidos, entre outros, com 12 empregados no máximo. Os empregados se misturavam entre familiares e conhecidos da familia. A tabela a seguir resume a caracterização das empresas entrevistadas.

Tabela 3 - Caracterização das Empresas da Feira dos Importados e do Guará (DF)

\begin{tabular}{|l|l|}
\hline Porte / Setor & Comércio e Serviços \\
\hline Microempresas (50 empresas) & Até 9 empregados \\
\hline Pequeno porte (30 empresas) & Até 12 empregados \\
\hline
\end{tabular}

Fonte: Elaboração do autor 
Vários negócios do mesmo ramo, com a mais de 2 anos de existência, trabalhavam lado a lado, lidando com uma concorrência acirrada em alguns cantos, solidariedade e cooperação em outros. Mais de $60 \%$, ou seja um pouco mais de 48 entrevistados, apresentaram necessidade de financiamento para dar continuidade ao negócio. A Tabela 4 apresenta as razões e os respectivos valores de acordo com o porte:

Tabela 4 - Razões e respectivos valores de empréstimos (valores em reais)

\begin{tabular}{|l|c|c|}
\hline \multicolumn{1}{|c|}{ Razões / Porte } & Micro Empresa & Pequena Empresa \\
\hline Capital de Giro & Até 6.000,00 & Até 10.000,00 \\
\hline $\begin{array}{l}\text { Despesas financeiras e legais } \\
\text { (fornecedores, impostos, } \\
\text { aluguel, pagamentos...) }\end{array}$ & Até 8.000,00 & Até 12.000,00 \\
\hline $\begin{array}{l}\text { Despesas Particulares } \\
\text { (capacitação, educação, } \\
\text { moradia, saúde...) }\end{array}$ & Até 5.000,00 & Até 8.000,00 \\
\hline Dívida com Banco & Até 2.000,00 & Até 4.000,00 \\
\hline Total & $20.000,00$ & $34.000,00$ \\
\hline
\end{tabular}

Fonte: Elaboração do autor

Vale ressaltar que a grande maioria dos entrevistados apresentou receio em fazer empréstimos bancários devido às altas taxas de juros. Eles temem se endividarem ainda mais ao adquirir crédito bancário. Explicaram também que se eles fossem pedir os empréstimos seria um problema de cada vez. Ou seja, no caso das empresas de pequeno porte, os empreendedores não pediriam os $R \$$ 20.000, mas começariam a investir no mais importante. Entre as mais importantes razões, foram capital de giro e problemas financeiros e legais, como apresentado na Tabela 4. Com esta análise, pode-se entender que os 
empreendedores têm alguns conhecimentos básicos de como gerenciar um negócio. Eles apresentaram um comportamento de responsabilidade e consciência ao definir as etapas necessárias para se chegar a ascensão tão procurada e resolução de seus problemas.

Após identificação da necessidade de empréstimo e os possíveis destinos dos mesmos, foi perguntado se eles sabiam à qual banco recorrer. Alguns identificaram a Caixa Econômica como o "menos pior" dos bancos, termo usado pelos entrevistados que já tinham procurado financiamento. Logo em seguida, procurou-se saber se tinham conhecimento de linhas de crédito destinado especialemente às MPEs. A Figura 5 a seguir ilustra o resultado desta pergunta.

Figura 5 - Conhecimento de linhas de crédito

\section{Conhecimentos de linhas de créditos}

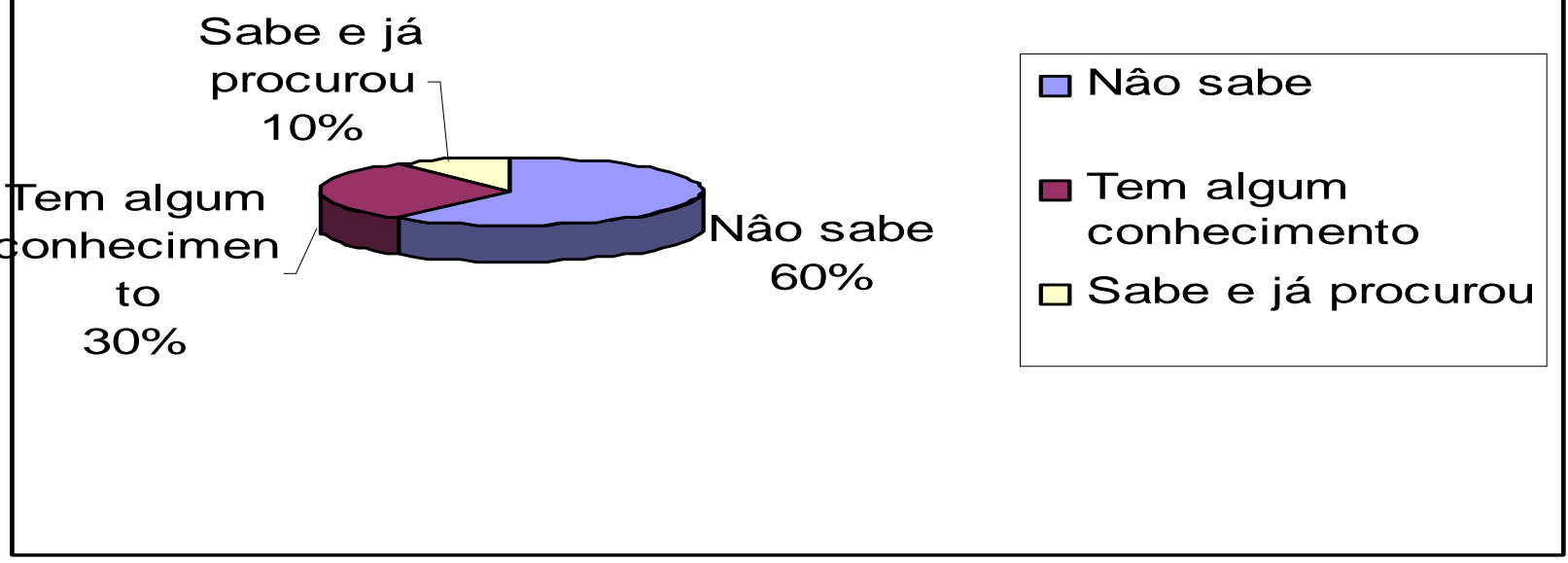

Fonte: Elaboração do autor

Pelo exposto na Figura 5, somente $10 \%$ dos entrevistados sabem e já procuraram as linhas de crédito na Caixa Econômica Federal e 30\% deles tem pouco conhecimento. E infelizmente, a grande maioria não sabe desses programas criados pelo governo federal e as instituições autorizadas. O máximo que sabiam era que o SEBRAE (Serviço Brasileiro de Apoio às Micro e 
Pequenas Empresas) ajuda as MPEs, mas o como disso eles não sabiam. Terminada a entrevista com o primeiro grupo, a próxima etapa foi identificar as linhas de crédito junto à CEF, apresentado nos próximos tópicos.

\subsection{Linhas de crédito da Caixa Econômica Federal}

Segundo dados obtidos durante a entrevista junto à um analista de crédito da CEF foram identificados os seguintes dados.

A CEF tem duas linhas de crédito ofertadas em condições especiais aos clientes de baixa renda:

- O Microcrédito Caixa que é uma operação diretamente com a Caixa. É um micro empréstimo destinado à pessoa física e aval solidário, especialmente no setor de comércio e serviços. O aval solidário é definido pela Caixa como "Grupo solidário, de indivíduos com interesses compartilhados, que, por meio de auto-seleção, potencializam atitudes de participação, organização, responsabilidade mútua de integração" e;

- O Microcrédito Produtivo Orientado que é uma metodologia de concessão de microcrédito, onde a instituição financeira ou IMF atua por meio de Agentes de Crédito, que prospectam e acompanham o pequeno empreendedor durante toda a vigência da operação, atuando como um consultor.

\subsubsection{Missão}

Para a caracterização do objetivo deste produto, foi informada tanto pela Intranet da Caixa quanto pelo analista a seguinte definição: "Conceder microcrédito destinado a capital de giro e/ou investimento fixo aos empreendedores populares de atividades produtivas de pequeno porte, pessoas físicas ou jurídicas, que atuam no setor formal ou informal da economia".

\subsubsection{Análise de risco da proposta de crédito}

O analista informou que ao receber uma prosposta de financiamento, ele se empenha primeiramente em efetuar um levantamento dos aspectos gerenciais e financeiros do empreendimento e do empreendedor popular, e com 
base neles analisa a viabilidade de crédito a ser concedido. A avaliação de risco de crédito é efetuada por dois sistemas automatizados. São eles o Sistema de Mensuração de Risco de Crédito (SIRIC) e o Sistema de Microfinanças e Correspondentes (SIMIC) que é um sistema desenvolvido em ambiente WEB e disponibilizado em dois módulos: SIMIC Intranet e SIMIC Internet. O SIMIC Internet tem como função possibilitar a concessão de microcrédito via WEB e o SIMIC Intranet define os parâmetros da operação de Microcrédito CAIXA, bem como o gerenciamento das informações das IMF conveniadas.

\subsubsection{Instituições de Microfinanças conveniadas}

As IMF são entidades que recebem repasses da Caixa, do Banco do Brasil e principalmente do BNDES, para executar atividades destinadas ao financiamento e fomento das MPEs. Os repasses são feitos por meio de recursos reajustados pela Taxa de Juros de Longo Prazo (TJLP) mais 1,5\%, sem os custos relativos ao risco, o chamado spread. As instituições se comprometem a conceder empréstimos aos microempreendedores a um juro máximo de $4 \%$ ao mês. São elas:

- Instituições Operadoras - IFO

- Instituições Financeiras Oficiais

- Bancos Comerciais

- Banco Múltiplos com carteira comercial

- Agente de Intermediação - AGI

- Agências de Fomento

- Bancos de Desenvolvimento

- Bancos Cooperativos

- Cooperativas Centrais de Crédito

- Instituições de Microcrédito Produtivo Orientado - IMPO

- Cooperativas de Crédito

- Agências de Fomento

- Organizações da Sociedade Civil de Interesse Público - OSCIP

- Sociedades de Crédito ao Microempreendedor - SCM 


\subsection{Abertura de conta}

Se a análise apresentar resultados positivos, é aberta uma conta corrente simplificada destinada à pessoa física, o que permite efetuar controles de limites de saldo e movimentação mensal. Não são emitidos de talão de cheques por motivos de segurança e os saldos são movimentados por meio de cartão magnético, pela Internet Banking CAIXA, ou em caráter excepcional, por meio de guia de retirada.

\subsubsection{Características do tomador de crédito}

Para ter acesso a essas linhas de crédito, o necessitado presica ter as seguintes características:

- Ser maior de 18 anos ou emancipado;

- Atuar há pelo menos 12 meses no empreendimento;

- Não possuir operação de empréstimo comercial ativa na CAIXA;

- Não possuir restrições cadastrais no CADIN (Cadastro Informativo dos Créditos não quitados do Setor Público Federal), SERASA (Centralização de Serviços dos Bancos S/A), SINAD (Sistema de Inadimplentes da CAIXA) e SPC(Serviço de Proteção ao Crédito);

- Ser aprovado em avaliação de risco de crédito;

- Assinar as Cláusulas Especiais do Contrato de Empréstimo Microcrédito CAIXA e Nota Promissória.

\subsubsection{Documentação}

Além dessas caracteristicas, são necessários alguns documentos para dar inicio ao processo. Alguns desses documentos podem servir de garantia. Para pessoa física, é preciso fornecer:

- Documento de identidade e comprovante da condição de inscrito no Cadastro de Pessoas Físicas - CPF, na situação regular, emitido via 
INTERNET, no endereço www.receita.fazenda.gov.br, do empreendedor e do(s) avalista(s), se for o caso;

- Comprovante de residência do empreendedor e do(s) avalista(s), quando for o caso;

- Comprovante de emancipação e do(s) avalista(s), quando for o caso;

- Comprovante de renda e do(s) avalista(s), quando for o caso

- Procuração do empreendedor e do(s) avalista(s), quando for o caso;

- Cópia do CPF do cônjuge que não necessita estar na situação de regular. As modalidades para pessoa jurídica são pouco diferentes em relação a pessoa física. Acrescenta-se, além dos documentos acima listados, a seguinte documentação:

- Comprovante da condição de inscrito no Cadastro Nacional de Pessoas Jurídicas - CNPJ, emitido via INTERNET, no endereço www.receita.fazenda.gov.br, ou cartão de inscrição no C.N.P.J. atualizado;

- Registro na junta comercial, se firma individual;

- Estatuto ou contrato social e alterações subseqüentes, se houver, devidamente registrados na Junta Comercial;

- Ata da Assembléia de eleição da Diretoria atual registrada, ou carta da Diretoria anterior apresentando a atual, acompanhada da Ata de Eleição e;

- Comprovante de opção, emitido via INTERNET, no endereço www.receita.fazenda.gov.br.

Como já foi explicado na parte teórica deste trabalho, o fornecimento de garantias é o maior dos problemas enfrentados pelas MPEs. Segundo a Caixa, são necessárias para Pessoa Física (PF):

- O Contrato e a Nota Promissória constituem a garantia da operação.

- Aval solidário: Para créditos individuais até $R \$ 2.000,00$;

- Aval de terceiros: para todos os contratos cujos proponentes não se enquadrem na metodologia do aval solidário. 
O aval, segundo o analista, é uma obrigação formal que serve de garantia e que decorre da simples assinatura do avalista em título de crédito, ou seja, o avalista indicado se obriga pelo afiançado, tornando-se co-devedor que pagará por ele a dívida caso o pagamento não for realizado no prazo pré-determinado.

No primeiro empréstimo, exigem-se esses documentos, e caso for feita uma renovação de operações de microcrédito, são dispensados as garantias acima, considerando-se o histórico de adimplência do cliente, desde que o valor da nova contratação não ultrapasse a $150 \%$ do valor da operação anterior.

No caso de uma operação a Pessoa Jurídica (PJ), são requeridos:

- Aval do(s) sócio(s);

- O Contrato e a Nota Promissória constituem a garantia da operação.

- A critério gerencial outras garantias podem ser negociadas entre a CAIXA e a IMF (Instituição de Microfinanças), tais como:

- Alienação Fiduciária;

- Qualquer outra garantia normativamente aceita pela CAIXA.

\subsubsection{Parâmetros do empréstimo}

Depois da identificação dos clientes, são informados os parâmetros que dizem respeito ao valor máximo e mínimo do empréstimo, os prazos, as taxas de juros, as tarifas, e tributos incidentes. Esses aspectos valem tanto para PF quanto para PJ. Segundo os dados fornecidos pelo analista, comprovados pelas informações na Intranet CAIXA, o valor mínimo de empréstimo é de $R$ \$250,00 e o máximo é de $\mathrm{R} \$ 5.000,00$, aplicados às taxas de juros pré-fixadas e consignadas no contrato firmado entre a CAIXA e a IMF. É aplicada uma Tarifa de Abertura de Crédito (TAC) de $3 \%$ sobre o valor do empréstimo, sendo de no mínimo $R \$ 15,00$ cobrados no ato da contratação.

Dependendo do projeto e o perfil do demandador de crédito, o valor do empréstimo é definido por meio da avaliação de risco de crédito. O prazo estipulado pela Caixa é de 1 a 12 meses, sem carência, para pagamento de 
dívida. As prestações são liquidadas através de boletos compensáveis, emitidos pela IMF no ato da contratação do empréstimo, na quantidade de parcelas escolhidas pelo empreendedor, sendo permitido pagamento nos terminais de auto-atendimento e na rede bancária até o vencimento.

\subsection{Liberação e acompanhamento do empréstimo}

Depois dessas formalidades, é liberado o crédito por meio de depósitos em conta, de titularidade do empreendedor, mantida na CAIXA. Vale acrescentar que a operação não termina depois da assinatura do contrato porque é realizado um acompanhamento do processo por um agente de IMF para garantir o bom uso dos recursos emprestados e um controle das operações do Microcrédito é realizado no Sistema de Aplicações (SIAPI) próprio da Caixa. A Figura 6 ilustra os procedimentos seguidos pela CEF para a execução das politícas de suas linhas de crédito e o apêndice A apresenta o fluxograma de concessão da operação Microcrédito do banco. 
Figura 6 - Modelo da operação Microcrédito da CEF

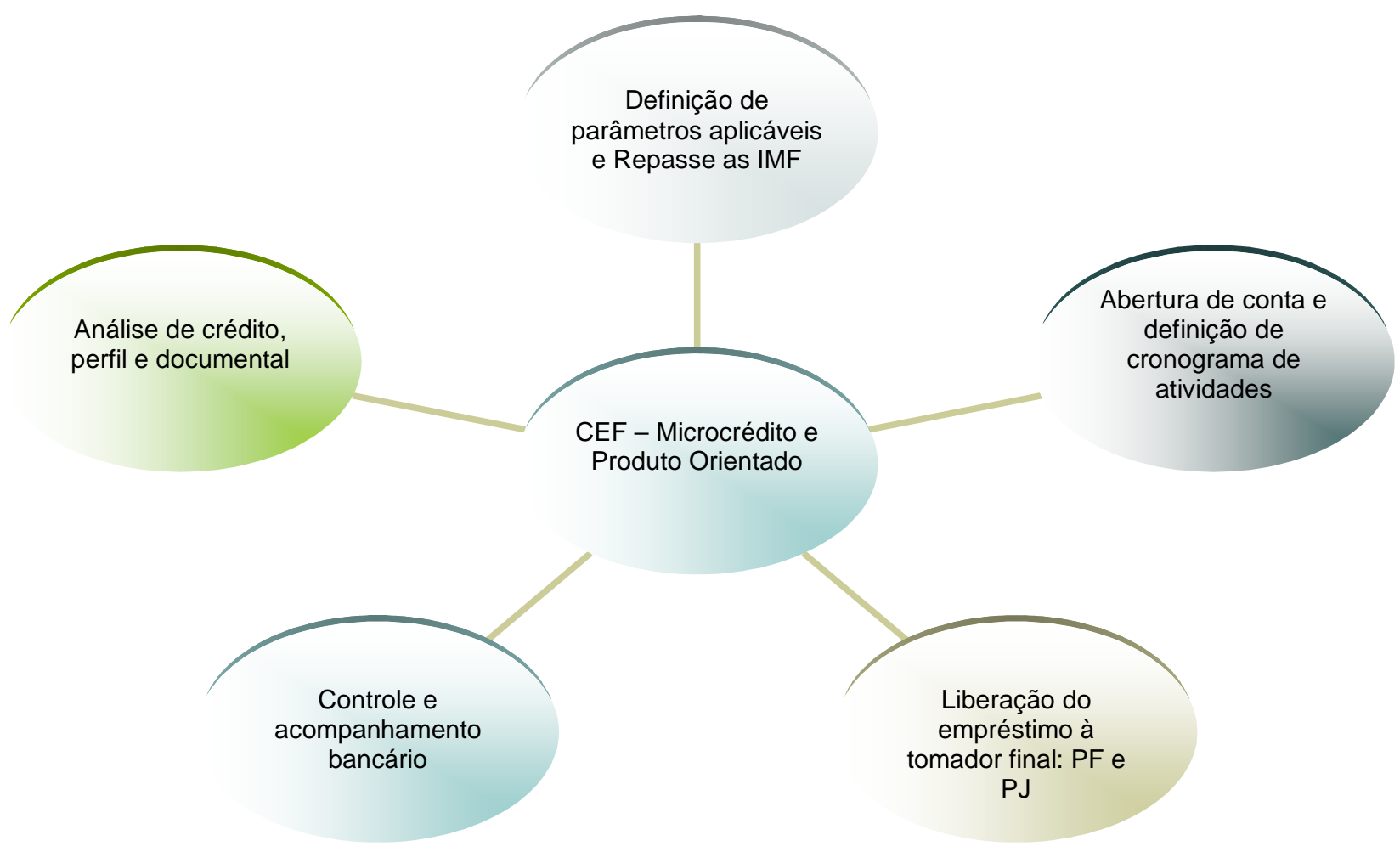

Fonte: Elaboração do autor

Com os dados obtidos, pode-se dizer que as duas linhas de crédito da Caixa apresentam um modelo bastante parecido com as Microfinanças por apresentar basicamente os mesmos aspectos. Segundo o analista, é um sistema que ainda está em processo de desenvolvimento, mas a análise de riscos de crédito é facilitada pelo sistema automatizado e especializado na avaliação de operações microfinanceiras. Entretanto, as condições de empréstimo são favoráveis tanto para a oferta quanto para a demanda quando é implantado o modelo das microfinanças que é baseado na oferta de crédito barato em troca de garantias mais flexíveis, expandindo assim a fronteira financeira à custos reduzidos e de uma forma segura. 


\section{CONSIDERAÇÕES FINAIS}

A instrumentos utilizados nesta pesquisa demonstraram-se eficiente por ter respondido ao questionamento da pesquisa e permitido o alcance dos objetivos previamente estabelecidos. Pôde-se provar que a grande maioria das micro e pequenas empresas procurem crescer, mas não possuem as condições legais e formais para terem acesso ao crédito bancário. A pesquisa bibliográfica demonstrou o quanto as MPEs são importantes para a economia devido à sua atuação significativa no PIB do país, além de explicar o comportamento bancário em relação à alguns indicadores como risco e retorno. Entendeu-se que os bancos aplicam os juros para diminuir o risco de não pagamento por parte do contratante de financiamento e que o retorno esperado é maximizado quanto mais altos forem os custos operacionais aplicados. A pesquisa de campo, por sua vez, demonstrou o quanto é vantajoso usar as microfinanças para operações de baixo valor, devido à eficiente aplicabilidade. Percebeu-se também que a implantação desta ferramenta econômica pode e deve se adequar à estrutura econômica do banco, do país e a relação custo-benefício da demanda existente. Por exemplo, no Brasil, o acompanhamento é feito pelo SEBRAE (Serviço Brasileiro de Apoio às Micro e Pequenas Empresas) que auxilia as MPEs nas questões empresariais, mas no modelo do Grameen Bank, é também o agente bancário que cuida desta parte.

Conclui-se que a elevada taxa de juros cobrada pelos bancos é consequência dos riscos envolvidos nas operações de crédito, da concorrência, das politicas e estratégias de cada instituição. Mas uma elevação do custo do crédito aumenta os casos de inadimplência, dificultando o acesso das MPEs no sistema financeiro. No sentido de criar condições favoráveis tanto para a demanda quanto para a oferta de crédito, é preciso combinar certo grau de modernidade e adequação das instituições financeiras ou organizações públicas e privadas, com boas práticas de políticas sociais e democráticas.

As microfinanças são aplicadas em diversas formas de maneira a adequá-las com as características de cada localidade, de cada banco, e 
conjuntura econômica de cada país. Este estudo de caso se focalizou na atuação da Caixa Econômica Federal por ter sido mencionada várias vezes e por ter facilitado 0 acesso às informações consideradas cruciais para a resolução do problema exposto no corpo do presente trabalho. Por meio da entrevista com um agente de crédito, demonstrou-se que a Caixa Econômica Federal promove a economia popular por meio da oferta de recursos para o microcrédito produtivo orientado a pessoas físicas e jurídicas empreendedoras de atividades produtivas de pequeno porte. O seu modelo, mesmo que este esteja em processo de desenvolvimento, permite atingir um dos objetivos das microfinanças: Oferecer créditos pessoais e empresariais em melhores condições por meio de linhas de microfinanças.

O uso de linhas de crédito com particularidades microfinanceiras depende da abordagem de cada instituição na busca de maior ou menor de modelos mais avançados. Revisão e upgrade de processos, investimentos em sistemas são soluções para aperfeiçoar práticas de gestão e supervisão de forma a minimizar os casos de inadimplência e os riscos de modo geral.

Estabilidade e desenvolvimento econômico, aumento do emprego e da renda, e maior segurança para os bancos emprestarem são consequências dos efeitos da expansão de empréstimos microfinanceiros que envolvem pequenos volumes. Infelizmente este resultado não pôde ser observado e comprovado em números devido ao sigilo de algumas informações. Alguns dados não foram liberados pelas empresas entrevistadas, impossibilitando a realização de um trabalho mais profundo e detalhado. Porém, espera-se que o estudo tenha contribuído de alguma forma e que tenha esclarecido possíveis dúvidas.

Por fim, recomenda-se ampliação dos meios de divulgação para que o público alvo e os potenciais clientes sejam efetivamente atendido, além da realização de mais estudos neste setor da economia para um maior desenvolvimento e alcance dos objetivos das Microfinanças. 


\section{REFERÊNCIAS}

AMARO, M. Nunes; PAIVA, S. M. Caldeira. Situação das Micro e Pequenas Empresas. Consultoria Legislativa, 2002.

ASSAF NETO, Alexandre. Mercado Financeiro - 4. Ed.- São Paulo: Atlas, 2001.

BANTERLI, Fábio R.; MONOLESCU, Friedhilde M. As micro e pequenas empresas no Brasil e sua importância para o desenvolvimento do país. São Paulo, 2007.

BACEN. www.bacen.gov.br. Último acesso em 15/05/2009.

BNDES. www.bndes.gov.br. Seção Micro, Pequena e Média Empresas, subseção Microfinanças. Último acesso em 15/05/2009.

BERNI, Mauro Tadeu. Operação e Concessão de Crédito: Os Parâmetros para a Decisão de Crédito. Atlas, 2002.

CAIXA ECONÔMICA FEDERAL. Relatórios Bancários - Operações de Microcrédito, 2008.

CARVAlHO, A. G.; L. C. Barcelos. Determinantes do Acesso ao Crédito Empresarial no Brasil, working paper, IPE-USP, 2002.

CASAROTTO Filho, Nelson; KOPITTKE, Bruno H. Análise de Investimentos. 9 ed. São Paulo: Atlas, 2000.

COLLI, J. Alexandre; FONTANA, Marino. Contabilidade Bancária. Atlas, 1996.

FERNANDES, Francisco et al. Dicionário Brasileiro GLOBO. 56 ed. São Paulo: Globo, 2003.

DUARTE, Antonio M. J. Risco: Definições, Tipos, Medição e Recomendações para seu Gerenciamento. Unibanco S.A. 1993.

HADDAD, Paulo R. Jovens lideranças no processo de desenvolvimento local endógeno. Revista Marco Social, p. 14-17, 2006.

MARCONI, Marina de Andrade; LAKATOS, Eva Maria. Técnicas de pesquisa. São Paulo, Atlas, 5ª Ed., 2002.

MARTINS, Paulo Haus. Manual de Regulamentação das Microfinanças: Programa de Desenvolvimento Institucional / Paulo Haus Martins, Andrei Winograd, Renata de Carvalho Salles. - Rio de Janeiro: BNDES, 2002. 
NITSCH, Manfred; SANTOS, Carlos A. Da repressão financeira ao microcrédito. Revista de Economia Política, vol. 21, n4 (84), 2001.

OTERO, Maria. Bringing Development Back into Microfinance. Journal of Microfinance, v. 1, n.1, 1999.

Portal do Microcrédito. www.portaldomicrocredito.com.br. Último acesso em 15/05/2009.

PREISLER, Adriano Milton. Análise de risco e crédito para micro e pequenas empresas - uma proposta orientativa. 180f. Dissertação (Mestrado em Engenharia de Produção). Programa de Pós-Graduação em Engenharia de Produção, UFSC, Florianópolis, 2003.

RATTNER, H. (Org.). Pequena empresa: o comportamento empresarial na acumulação e na luta pela sobrevivência. São Paulo: Brasiliense, v. 2, 1985.

SARDONI, C. Marx and Keynes on effective demand and unemployment. History of Political Economy, v. 18, n. 3, p. 419-441, 1986.

SEBRAE. As Empresas de Menor Porte na Economia Nacional. Disponível: www.sebrae.com.br. Último acesso em 18/04/2009.

SILVA, José Pereira da. Gestão e Análise de Risco de Crédito. Editora Atlas, 2004.

STIGLITZ, J.; A. WEISS. Credit Rationing in Markets with Imperfect Information, American Economic Review, vol. 71 (3), pág. 393-410, 1981. 


\section{GLOSSÁRIO}

Crédito: valor em dinheiro emprestado ou posta à disposição de alguém, em estabelecimento bancário ou comercial.

Microfinanças: Finanças de produtos destinados à micro e pequenos empreendedores.

Risco: probabilidade de não recebimento do valor emprestado.

Retorno: restituição da soma emprestada.

Spread: Receita financeira decorrente da diferenca entre a taxa de aplicação e a taxa de captação de recursos financeiros.

Stricto sensu: restrito em latino.

Upgrade: actualização.

Win-win situation: situação ou condição em que ambas as partes de uma operação lucram. 


\section{APÊNDICES}

\section{Apêndice A - Questionário às Micro e Pequenas Empresas (Feira dos Importados e Feira do Guará)}

Prezado (a) $\mathrm{Sr}$ (a), Agradeço sua colaboração nesta pesquisa acadêmica. $O$ objetivo é levantar sua presente opinião acerca de questões relacionadas ao empreendimento em que o (a) $\mathrm{Sr}$ (a) trabalha. O questionário é anônimo e o preenchimento do questionário tomará cerca de 10 minutos.

1) Qual é o ramo/setor do presente empreendimento?
a) Comércio
c) Serviços
b) Indústria
d) Construção

2) Qual é o porte do empreendimento?
a) Microempresa (de 1 a 19 empregados)
b) Pequeno porte (de 20 a 99 empregados
c) Médio porte (de 100 a 499 empregados)
d) Grande porte (de 500 a mais empregados)

3) Por quais motivos decidiu-se abrir o negócio?

4) Abriu-se o negócio com:
a) Capital próprio (pule para a pergunta 5)
b) Crédito bancário (pule para a pergunta 6 )

5) Por quais motivos você optaria por um financiamento bancário?
a) Capital de giro
b) Exportação/Importação
c) Problemas financeiros (dívidas, fornecedores, impostos...)

6) Qual foi/seria o Banco?
a) Banco do Brasil
d) BNDES
b) Caixa econômica
e) Itaú
c) Bradesco
f) Outros:

7) Houve dificuldades? Se sim, quais?
a) Altas taxas de juros
b) Falta de informação (plano de negócio, demonstrativos, etc...)
c) Garantias
d) Incompatibilidade do negócio com o valor solicitado
e) Outros: 
8) Em caso de não obtenção do empréstimo, que outros meios de financiamento de atividades são utilizados para dar continuidade ao negócio?
a) Amigos
b) Família
c) Venda de bens
d) Agiota
e) Cheques pré-datados
f) Declaração de fechamento/falência
g) Outros:

9) Na sua opinião, o que é um empreendedor?

10) Considerações finais? 


\section{Apêndice B - Questionário à Caixa Econômica Federal}

Prezado (a) $\mathrm{Sr}$ (a),

Agradeço sua colaboração nesta pesquisa acadêmica. $O$ objetivo é levantar sua presente opinião e dados complementares acerca de questões relacionadas à politícas e comportamento desta instituição em relação as Micro e Pequenas Empresas. 0 questionário é anônimo e o preenchimento do questionário tomará cerca de 10 minutos.

1) O que é risco de crédito segundo as politícas do Banco?

2) Quais são os tipos de risco que influenciam a concessão de crédito?

3) Como é mensurado o risco?
a) Histórico da empresa ou cliente
b) Avaliação qualitativa
c) Avaliação quantitativa
d) Sistema automatizado
e) Outros:

4) Existem linhas de crédito para micro e pequenos empresários neste banco? Se sim, quais?

Se não, pular para a pergunta 5 .

5) Como é feita a segmentação do portfólio do banco?

6) Quais são os procedimentos do pedido de empréstimos? 0 que o empresário precisa fornecer?
a) Plano de negócio
b) Demonstrativos
c) Preenchimento de ficha de pedido de crédito
d) Proposta de crédito

7) Como é o processo decisório para a seleção dos tomadores de empréstimo ou critérios seguidos pelo seu banco para aprovação de empréstimos?

8) Existe algum tipo de acompanhamento interno bancário e da empresa/cliente por parte do banco?

9) Em caso de não pagamento e/ou inadimplência, o que é realizado para conter a situação?

10) A recente crise influenciou positiva ou negativamente a procura de créditos por MPEs? 


\section{ANEXOS}

\section{ANEXO A - FLUXOGRAMA DE CONCESSÃO DA OPERAÇÃO MICROCRÉDITO DA CAIXA ECONÔMICA FEDERAL}

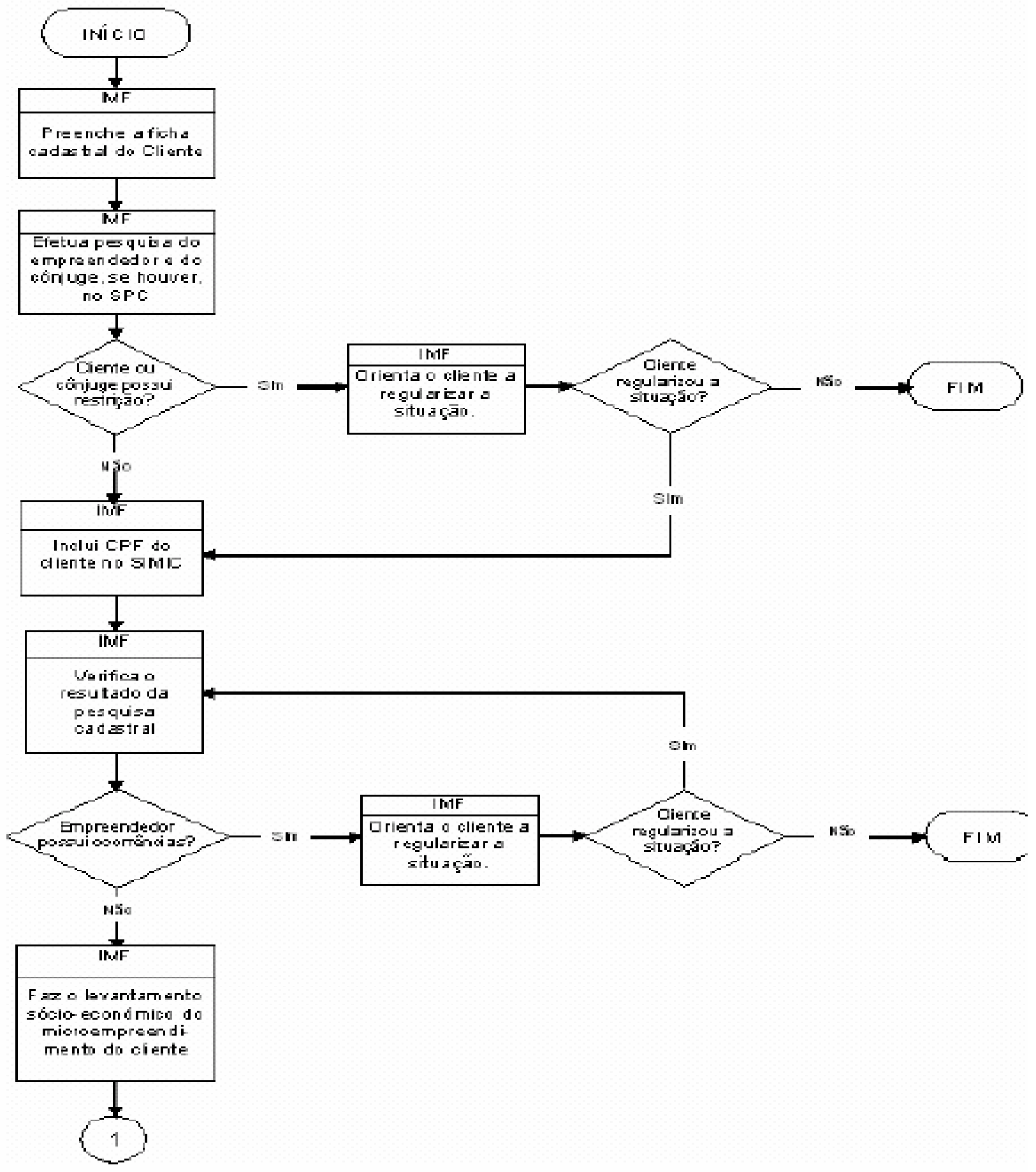




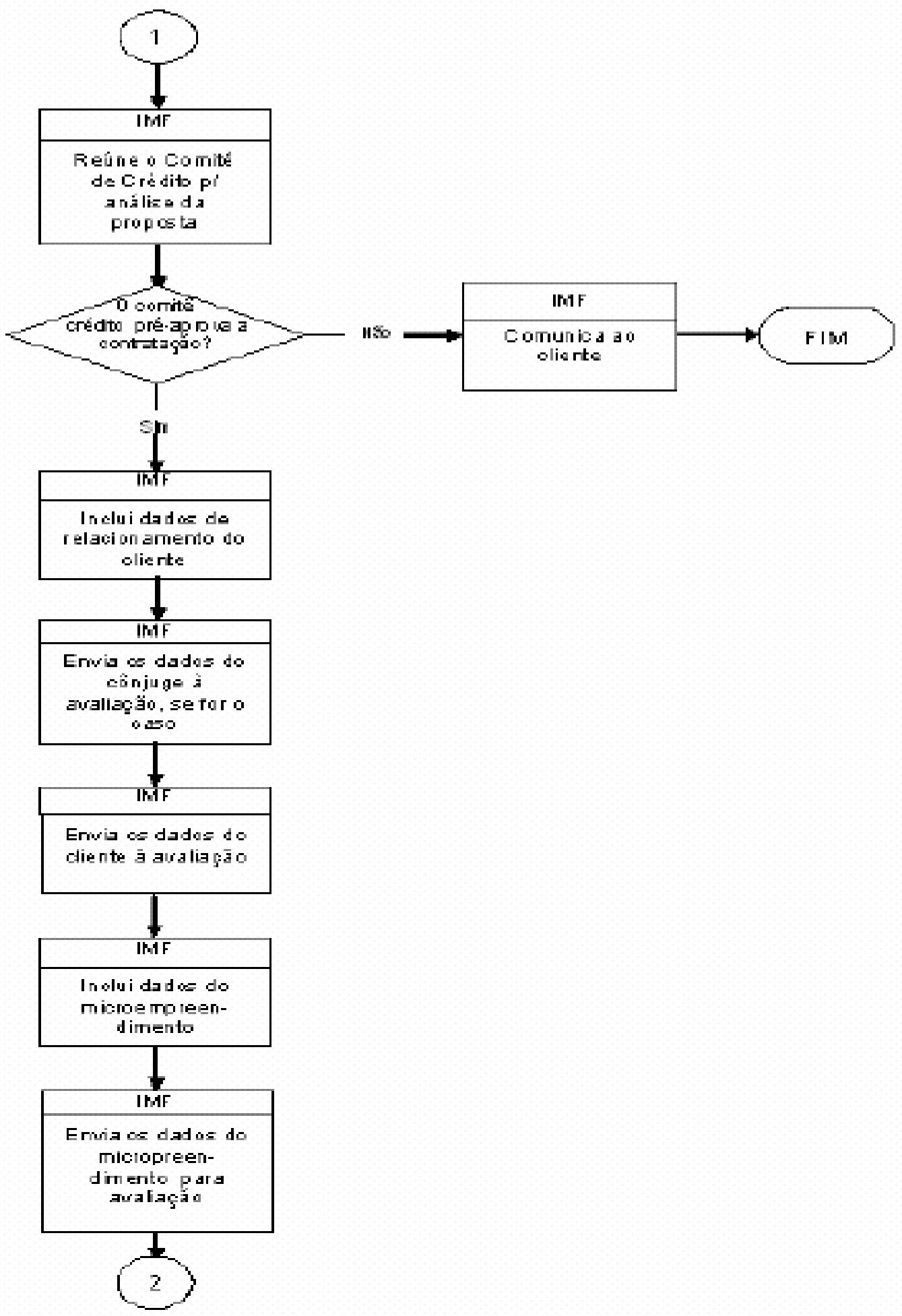




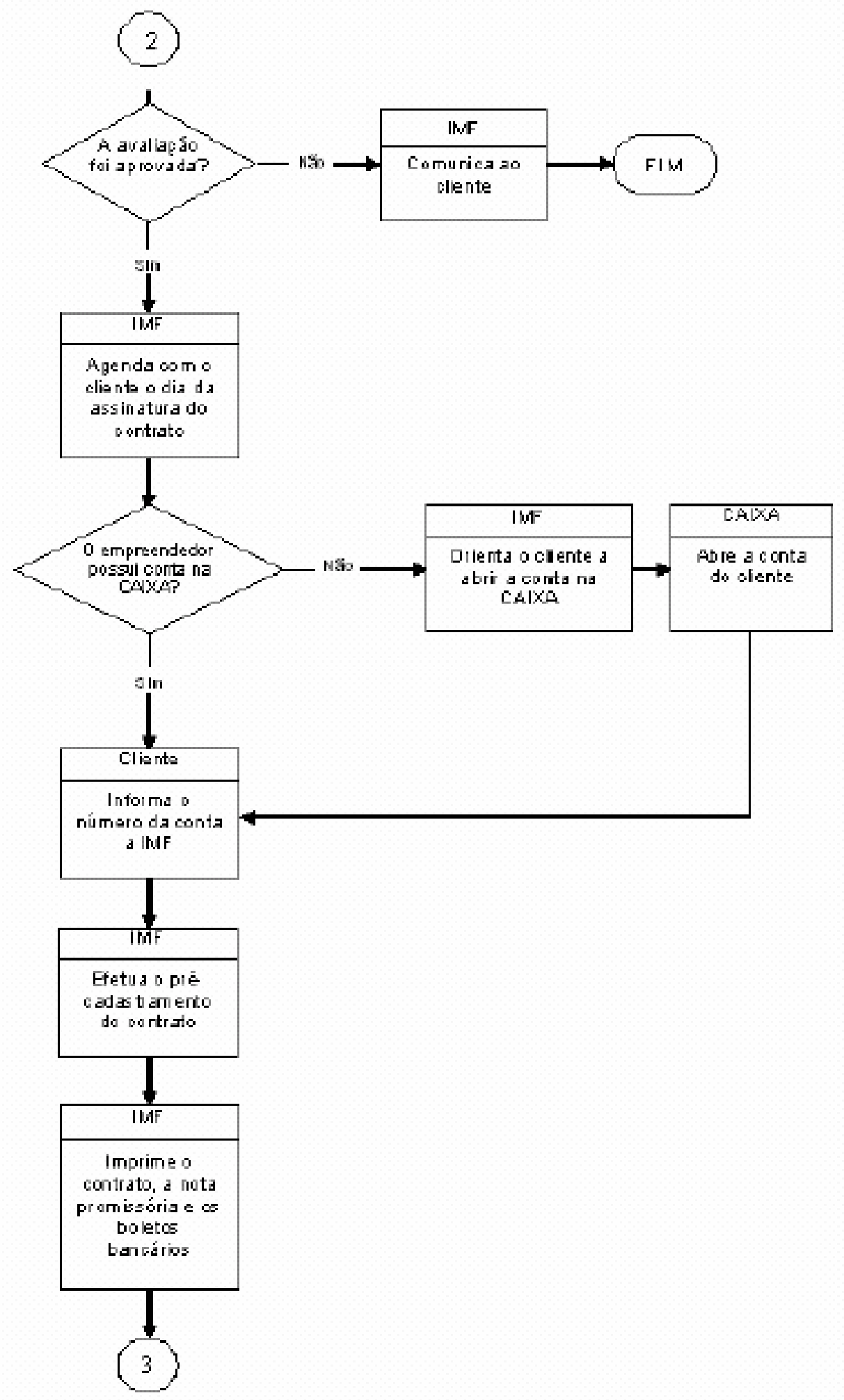




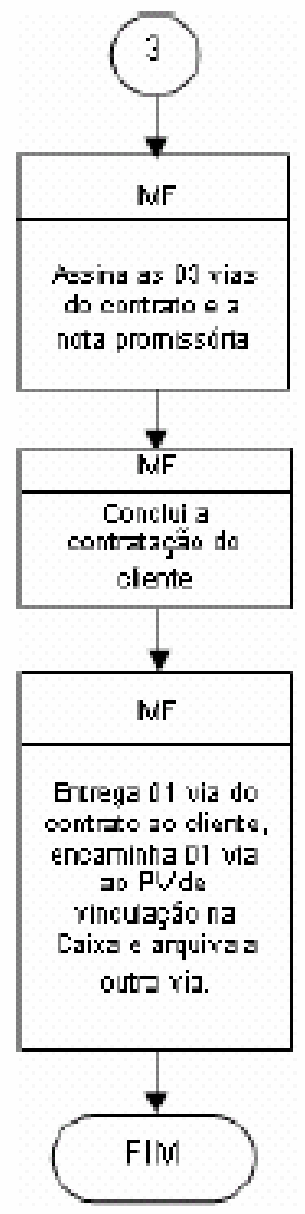

